\title{
Electrochemical Routes for Industrial Synthesis
}

\author{
C. A. C. Sequeira and D. M. F. Santos* \\ ICEMS-DEQB, Instituto Superior Técnico, TU Lisbon, Av. Rovisco Pais, 1049-001 Lisboa, Portugal
}

\begin{abstract}
Esta revisão examina as razões que justificam um interesse crescente da indústria química pelos processos eletrolíticos. Reveem-se as indústrias químicas, nas quais compostos orgânicos e inorgânicos são processados e descrevem-se os avanços tecnológicos mais relevantes. Inicialmente, abordam-se processos bem estabelecidos, como as indústrias cloroalcalinas de produção de alumínio, p-aminofenol, adiponitrila, etileno glicol, antraquinona, produtos perfluorados, ácido glioxílico e L-cisteína. Face à grande quantidade de informação disponível, o assunto é tratado com base científica, mas de modo bastante simplificado. Posteriormente, descrevem-se processos orgânicos e inorgânicos emergentes, nomeadamente processos eletroquímicos mediados e síntese em líquidos iónicos. Estabelecem-se paralelos entre síntese química e síntese eletroquímica. Estimula-se o interesse nos processos de eletrossíntese, particularmente em líquidos iónicos, não desmerecendo a importância das vias puramente químicas de síntese orgânica e inorgânica.
\end{abstract}

This review examines the reasons for increasing interest towards electrolyses by the chemical industry, reviews the electrochemical industries as most of them now exist, and provides a status report on the key technological advances which are occurring to meet present and future needs. Classical industries like those of chloroalkali, aluminium, $p$-aminophenol, adiponitrile, ethylene glycol, anthraquinone, perfluorinated products, glyoxylic acid and $L$-cysteine are initially covered. Considering the large amount of available publications in these topics of electrochemical engineering, the covered relevant information is treated at a scientific level, although in a simplified way. Then the paper deals with emerging inorganic and organic processes, e.g. electrosynthesis in ionic liquids and mediated electrochemical processes, and finishes by assessing what the future development trend might be given the electrochemical and non electrochemical competing influences. With this approach it is hoped to stimulate the interest of chemical engineers and scientists non-specialised in electrochemical routes, and to review some cutting edge research, particularly as far as electrosynthesis in ionic liquids is concerned.

Keywords: electrochemical synthesis, organic chemicals, scale-up electroorganic processes, emerging inorganic processes, ionic liquids

\section{Introduction}

Electrons are inherently "environmentally friendly", at least at the site of use. Off-site arguments can be made about the relative merits and problems of hydro power, wind, solar, nuclear, fossil fuel based power generation etc. This means that in some electrochemical processes less by-product waste compared to chemical processes can generally be expected. For example, catalytic quantities of electrochemically regenerable redox couples can be used for oxidation or reduction reactions instead of stoichiometric quantities of redox reagents (so called, indirect electrolysis). If, however, electron transfer is direct,

*e-mail: cesarsequeira@ist.utl.pt; diogosantos@ist.utl.pt from substrate to electrode (anodic oxidation) or electrode to substrate (cathodic reduction), pollutant levels can be even further decreased.

Still, other important reasons for industrial interest include: possible overall higher energy efficiency of electrochemical compared to thermally-based processes $;{ }^{1-5}$ use of less expensive starting materials; less aggressive process conditions, e.g. lower temperatures with less degradation of feed and/or product; fewer processing steps (for example, electrochemical synthesis and product separation may be combined in one reactor); precise control of oxidation or reduction level by control of electrode potential; discovery of unique processing routes to establish or re-establish control of the market position. ${ }^{6-16}$ 
In any worthwhile comparison of the advantages of chemical vs. electrochemical alternatives, it is obvious that the relative economics, the market, product selectivity and other factors must be considered. Certainly, electrochemical routes are not always economically feasible, especially when the competitor is a catalytic chemical route based upon $\mathrm{O}_{2}$ or $\mathrm{H}_{2}$. Product quality is also important, and typically an electrochemical process originates products more pure than those synthesised by the chemical route. ${ }^{17}$ Although, as strange as it may seem, in very special cases failure of an electrochemical process can occur precisely because the product is too pure when compared to the one obtained chemically. For example, certain anthraquinone dyes produced by chemical means contain coloured by-products in addition to the major product, and the mixture of a particular colour may have been accepted for decades by a very conservative industry.

The present article is a review about industrial electrosynthesis, whose aim is to contribute to the diffusion of the interest of the electrochemistry applied to the industry. It summarises the most recent electrode processes, including paired reactions and the use of ionic liquids in electrosynthesis of organic and inorganic compounds.

\section{Electrosynthesis Industries}

\subsection{Inorganic chemicals}

The aluminium and chloroalkali industries together account well for over $90 \%$ of the electricity used in electrolytic processes. Aluminium is the larger of the two regarding energy usage while chloroalkali is the largest in tonnage. Table 1 summarises equations, anode and cathode materials, and electrolysis conditions for aluminium, chloroalkali as well as several other important inorganic electrochemical processes. Not listed in Table 1 but also of considerable importance are hypochlorite generation from brine; dichromate from chromium sulphate solutions; electrowinning of metals such as $\mathrm{Li}, \mathrm{Na}, \mathrm{K}, \mathrm{Mg}, \mathrm{Cu}, \mathrm{Zn}$ etc; electrosynthesis of various metal salts like sodium stannite from $\mathrm{Sn}$, and oxides such as $\mathrm{Cu}_{2} \mathrm{O}$ and $\mathrm{CuO}$ from $\mathrm{Cu}$; electrosynthesis of organometallics like tetraalkyl lead and various metal acetates; and other carboxylate salts. The inorganic chemicals cited in Table 1 are produced in many companies worldwide, namely: Aluminium - Alusiusse Co., Alcoa, Reynolds Metal Co., Comaleo Co., Moltech Co.; Chlorine/Caustic Soda - OxyTech Systems, INEOS, Braskem; Chloride - Occidental Chemical Co., Albright and Wilson Americas; Perchlorate - All-Chemie, Hebei Shengyuan Metal Co.; Persulphate - Hengshui Jiheng Corp., Unionchimica Industriale; Permanganate - Carus
Chemical Co., Chongking Jialing Chemical Products Ltd.; Fluorine - INEOS, Union Carbide, BNFC plc, Allied Chemical Corp.; Manganese Dioxide - Xiangtan Electrochemical Science and Technology Co. Ltd., HiTEc Energy Ltd.; Water electrolysis - Atomic Energy of Canada Ltd., Ontario Hydro, General Electric Co.; Hydrogen Peroxide - Dow Chemical Co., Huron Chemicals, DH Tech Inc.; Ozone - Ozonia Int., OxyTech Systems.

The variety of electrolysis conditions described in Table 1 should be noted. Aluminium production occurs by electrolysis of molten cryolite in undivided batch cells (Figure 1) at about $1000{ }^{\circ} \mathrm{C}$ and at high current densities, around $1 \mathrm{~A} \mathrm{~cm}^{-2}$. 1,18

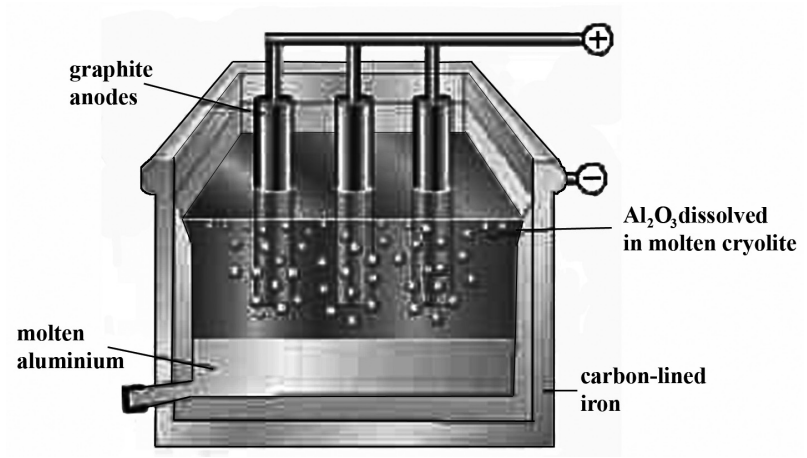

Figure 1. Hall-Heroult cell for aluminium production.

The carbon anode is consumed in the process. In contrast, chlorine and caustic soda, along with hydrogen, are manufactured by electrolysis of concentrated (25 wt.\%) brine solutions at $80-95^{\circ} \mathrm{C}$ at lower current densities (about $150-250 \mathrm{~mA} \mathrm{~cm}^{-2}$ ) in porous diaphragm and in ion exchange membrane cells. ${ }^{19}$ Persulphate requires a noble metal anode, cooling, and high current densities. ${ }^{20,21}$ Hydrogen peroxide as a 1 to $2 \%$ solution is produced cathodically by reduction of $\mathrm{O}_{2}$ at special carbon cathodes. ${ }^{18,22}$ Ozone is generated anodically on vitreous carbon anodes in cold, concentrated $\mathrm{HBF}_{4}$ solutions or at specialised solid polymer electrolyte composites of $\mathrm{PbO}_{2}$ deposited on an ion exchange membrane with an analyte of pure water. ${ }^{18,23}$

The chloroalkali industry has been a prime leader in electrolyser advances since late 1960's. Until then, the industry contended with severe mercury pollution problems from mercury cathode cells, corrosion of carbon-based anodes (also leading to chlorinated by-products), environmental/safety problems with asbestos diaphragms and high energy costs. Today, this industry has largely switched over to long-lasting titanium anodes coated with noble metal oxide (e.g. $\mathrm{RuO}_{2} / \mathrm{Ti}$ ) and greatly improved cell designs with narrower inter-electrode gaps for considerable savings in energy costs (Figure 2). Perfluorinated ion-exchange membranes, such as DuPont 
Table 1. Some inorganic electrochemical processes

\begin{tabular}{|c|c|c|c|}
\hline Chemical & Equation $^{\mathrm{a}}$ & $\begin{array}{l}\text { Anode (A) } \\
\text { Cathode (C) }\end{array}$ & Conditions \\
\hline Aluminium ${ }^{24}$ & $\begin{array}{l}2 \mathrm{Al}_{2} \mathrm{O}_{3}+3 \mathrm{C} \rightarrow 4 \mathrm{Al}+3 \mathrm{CO}_{2} \\
\mathrm{E}_{0}=-1.16 \mathrm{~V}\left(1010^{\circ} \mathrm{C}\right)\end{array}$ & $\begin{array}{l}\text { Carbon }(\mathrm{A}) \\
\text { Aluminium }(\mathrm{C})\end{array}$ & $\begin{array}{l}\text { Molten cryolite, } \mathrm{Al}_{2} \mathrm{O}_{3} \\
1000{ }^{\circ} \mathrm{C} ; 1 \mathrm{~A} \mathrm{~cm}^{-2} ; 4.3 \mathrm{~V}\end{array}$ \\
\hline $\begin{array}{l}\text { Chlorine/ } \\
\text { Caustic soda }\end{array}$ & $\begin{array}{l}2 \mathrm{NaCl}(\mathrm{aq})+2 \mathrm{H}_{2} \mathrm{O} \rightarrow \\
\mathrm{Cl}_{2}(\mathrm{~g})+\mathrm{H}_{2}(\mathrm{~g})+2 \mathrm{NaOH} \\
\mathrm{E}_{0}=-1.36 \mathrm{~V}\end{array}$ & $\begin{array}{l}\text { Noble Metal Oxide/Ti (A) } \\
\text { Steel or } \mathrm{Hg}(\mathrm{C})\end{array}$ & $\begin{array}{l}\text { Aqueous } \mathrm{NaCl} \text {; asbestos or ion-exchange } \\
\text { membrane; } 80-95{ }^{\circ} \mathrm{C} ; 200-1000 \mathrm{~mA} \mathrm{~cm}{ }^{-2}\end{array}$ \\
\hline $\begin{array}{l}\text { Chloride } \\
\mathrm{Na}^{+}\end{array}$ & $\begin{array}{lc}2 \mathrm{Cl}^{-} \rightarrow \mathrm{Cl}_{2}+2 \mathrm{e}^{-} & \mathrm{E}^{0}=1.36 \mathrm{~V} \\
2 \mathrm{H}_{2} \mathrm{O}+2 \mathrm{e}^{-} \rightarrow 2 \mathrm{OH}^{-}+\mathrm{H}_{2} & \mathrm{E}^{0}=0.0 \mathrm{~V} \\
2 \mathrm{HOCl}+\mathrm{OCl}^{-} \rightarrow \mathrm{ClO}_{3}^{-}+2 \mathrm{Cl}^{-}+2 \mathrm{H}^{+} & \end{array}$ & $\begin{array}{l}\text { Noble Metal Oxide/Ti (A) } \\
\text { Steel (C) }\end{array}$ & $\begin{array}{l}\text { Aqueous } \mathrm{NaCl}\left(310 \mathrm{~g} \mathrm{dm}^{-3}\right) \\
\mathrm{Na}_{2} \mathrm{Cr}_{2} \mathrm{O}_{7}\left(1-6 \mathrm{~g} \mathrm{dm}^{-3}\right) \\
60-80^{\circ} \mathrm{C} ; 150-400 \mathrm{~mA} \mathrm{~cm}^{-2}\end{array}$ \\
\hline $\begin{array}{l}\text { Perchlorate } \\
\mathrm{Na}^{+}, \mathrm{NH}_{4}^{+} \\
\end{array}$ & $\begin{array}{l}\mathrm{ClO}_{3}^{-}+\mathrm{H}_{2} \mathrm{O} \rightarrow \mathrm{ClO}_{4}^{-}+2 \mathrm{H}^{+}+2 \mathrm{e}^{-} \\
\mathrm{E}^{0}=1.19 \mathrm{~V}\end{array}$ & $\begin{array}{l}\mathrm{Pt} / \mathrm{Ti}, \mathrm{PbO}_{2} / \text { Graphite }(\mathrm{A}) \\
\mathrm{Steel} \text { or } \mathrm{Ni}(\mathrm{C})\end{array}$ & $\begin{array}{l}\text { Aqueous } \mathrm{ClO}_{3}^{-} ; \mathrm{Na}_{2} \mathrm{Cr}_{2} \mathrm{O}_{7} \\
35-50^{\circ} \mathrm{C} ; 150-500 \mathrm{~mA} \mathrm{~cm}^{-2}\end{array}$ \\
\hline $\begin{array}{l}\text { Persulphate } \\
\mathrm{Na}^{+}, \mathrm{NH}_{4}^{+}, \mathrm{H}^{+} \\
\end{array}$ & $\begin{array}{l}2 \mathrm{SO}_{4}^{2-} \rightarrow \mathrm{S}_{2} \mathrm{O}_{8}^{2-}+2 \mathrm{e}^{-} \\
\mathrm{E}^{0}=2.01 \mathrm{~V}\end{array}$ & $\mathrm{Pt}$ or $\mathrm{Pt} / \mathrm{Ti}(\mathrm{A})$ & $\begin{array}{l}\text { Conc. } \mathrm{H}_{2} \mathrm{SO}_{4} \text {, cold; } \\
500-1000 \mathrm{~mA} \mathrm{~cm}{ }^{-2} \text {; divided cell }\end{array}$ \\
\hline $\begin{array}{l}\text { Permanganate, }{ }^{28} \\
\mathrm{~K}^{+}\end{array}$ & $\begin{array}{l}\mathrm{MnO}_{4}^{2-} \rightarrow \mathrm{MnO}_{4}^{-}+\mathrm{e}^{-} \\
\mathrm{E}^{0}=0.54 \mathrm{~V}\end{array}$ & $\begin{array}{l}\mathrm{Ni}, \text { Monel (A) } \\
\text { Fe or Steel (C) }\end{array}$ & $\begin{array}{l}\mathrm{K}_{2} \mathrm{MnO}_{4}\left(25-100 \mathrm{~g} \mathrm{dm}^{-3}\right) \\
1-4 \mathrm{~mol} \mathrm{~L}^{-1} \text { aq. } \mathrm{KOH} \text { at } 60{ }^{\circ} \mathrm{C} \\
5-150 \mathrm{~mA} \mathrm{~cm}^{-2} ; \text { undivided cell } \\
\end{array}$ \\
\hline Fluorine $^{18}$ & $\begin{array}{l}2 \mathrm{~F}^{-} \rightarrow \mathrm{F}_{2}+2 \mathrm{e}^{-} \\
\mathrm{E}^{0}=2.87 \mathrm{~V}\end{array}$ & $\begin{array}{l}\text { Carbon (A) } \\
\text { Mild steel (C) }\end{array}$ & $\begin{array}{l}\mathrm{KF}-2 \mathrm{HF} \text { (eutectic) at } 82^{\circ} \mathrm{C} \text {; } \\
13 \mathrm{~mA} \mathrm{~cm}-2 \text {; undivided cell (skirt) }\end{array}$ \\
\hline $\begin{array}{l}\text { Manganese }^{18} \\
\text { Dioxide }\end{array}$ & $\begin{array}{l}\mathrm{Mn}^{2+}+2 \mathrm{H}_{2} \mathrm{O} \rightarrow \mathrm{MnO}_{2}+4 \mathrm{H}^{+}+2 \mathrm{e}^{-} \\
\mathrm{E}^{0}=1.23 \mathrm{~V}\end{array}$ & Graphite, $\mathrm{Pb}$ or $\mathrm{Ti}(\mathrm{A})$ & $\begin{array}{l}\mathrm{MnSO}_{4}\left(0.5-1.2 \mathrm{~mol} \mathrm{~L}^{-1}\right) \text { in aq. } \mathrm{H}_{2} \mathrm{SO}_{4} \text { at } \\
90-100^{\circ} \mathrm{C} ; \\
7-12 \mathrm{~mA} \mathrm{~cm}^{-2} ; \text { undivided cell }\end{array}$ \\
\hline $\begin{array}{l}\text { Water } \\
\text { Electrolysis }^{29} \\
\end{array}$ & $\begin{array}{ll}2 \mathrm{H}_{2} \mathrm{O}+2 \mathrm{e}^{-} \rightarrow \mathrm{H}_{2}+2 \mathrm{OH}^{-} & \mathrm{E}^{0}=0.0 \mathrm{~V} \\
2 \mathrm{OH}^{-} \rightarrow \mathrm{O}_{2}+2 \mathrm{H}^{+}+4 \mathrm{e}^{-} & \mathrm{E}^{0}=1.23 \mathrm{~V}\end{array}$ & $\begin{array}{l}\text { Ni plated on steel (A) } \\
\text { Steel (C) }\end{array}$ & $\begin{array}{l}\text { Aq. } \mathrm{KOH}(25-30 \text { wt. } \%) \text { at } 70^{\circ} \mathrm{C} \text {; divided } \\
\text { cell (asbestos) }\end{array}$ \\
\hline $\begin{array}{l}\text { Hydrogen } \\
\text { Peroxide }^{26} \\
\end{array}$ & $\begin{array}{l}\mathrm{O}_{2}+\mathrm{H}_{2} \mathrm{O}+2 \mathrm{e}^{-} \rightarrow \mathrm{HO}_{2}^{-}+\mathrm{OH}^{-} \\
\mathrm{HO}_{2}^{-}+\mathrm{H}_{2} \mathrm{O} \rightarrow \mathrm{H}_{2} \mathrm{O}_{2}+\mathrm{OH}^{-} \mathrm{E}^{0}=0.68 \mathrm{~V}\end{array}$ & Graphite or carbon (C) & $\begin{array}{l}1 \mathrm{~mol} \mathrm{~L}-1 \text { aq. } \mathrm{NaOH} \text {, cold; } \\
25-150 \mathrm{~mA} \mathrm{~cm}^{-2} \text {; divided cell }\end{array}$ \\
\hline Ozone $^{18}$ & $\begin{array}{l}\mathrm{O}_{2}+\mathrm{H}_{2} \mathrm{O} \rightarrow \mathrm{O}_{3}+2 \mathrm{H}^{+}+2 \mathrm{e}^{-} \\
\mathrm{E}^{0}=2.07 \mathrm{~V}\end{array}$ & Vitreous carbon (A) & Conc. aq. $\mathrm{HBF}_{4}$, cold; $500 \mathrm{~mA}$; divided cell \\
\hline
\end{tabular}

${ }^{a}$ Standard potentials, $\mathrm{E}^{0}$, under the IUPAC convention. $\mathrm{E}_{0}$ is the reversible cell voltage.

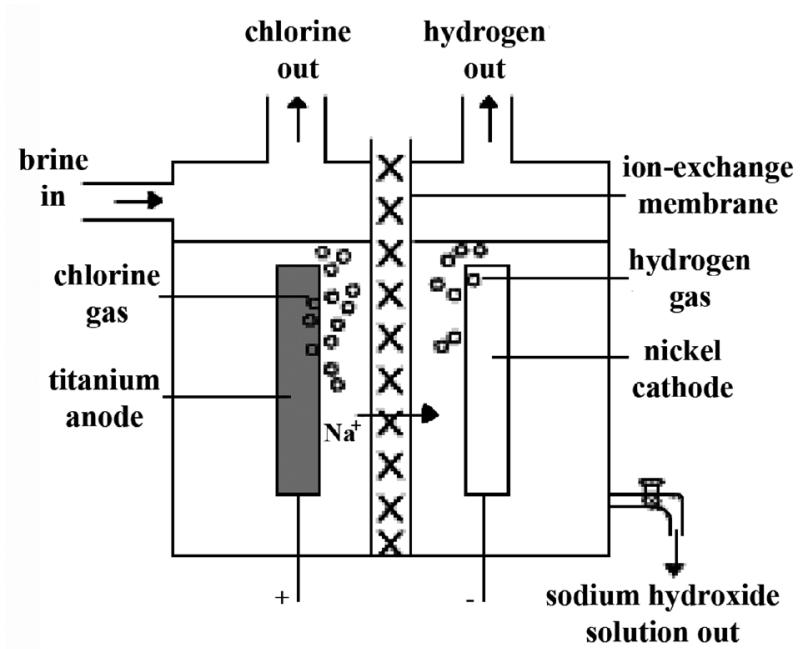

Figure 2. Ion-exchange membrane chloroalkali cell.

Nafion ${ }^{\circledR}$ membranes, are gradually replacing asbestos separators..$^{30,31}$

These membranes produce 15 to $40 \%$ caustic soda solutions virtually free of chloride, compared to a mixture of about $15 \% \mathrm{NaOH} / 15 \% \mathrm{NaCl}$ from asbestos diaphragm cells which then required much higher energy costs for separation and concentration to $50 \% \mathrm{NaOH}$. It is of interest that aluminium and chloroalkali are not immune to the environmental, energy and feedstock problems mentioned above. The USA is witnessing a shift away from aluminium manufacture because of lower energy and raw material costs in Europe and China. ${ }^{32}$ Likewise, chloroalkali is experiencing pressure from decreased sales of chlorine because of polychlorinated hydrocarbons found in chlorinebleached pulp products and their harmful impact. ${ }^{33}$ As a result, bleaching of pulp by $\mathrm{ClO}_{2}$, produced from chloride, is on an downswing, while other non-chlorinating bleaches such as $\mathrm{H}_{2} \mathrm{O}_{2}, \mathrm{O}_{3}$ and persulphate are strengthening. The price of caustic soda has escalated at this time, ${ }^{34,35}$ and salt splitting by electrodialysis of salts like $\mathrm{Na}_{2} \mathrm{SO}_{4}$, to produce caustic soda and sulphuric acid, is being actively investigated by a number of companies. ${ }^{36-41}$

\subsection{Organic chemicals}

Industrial scale electrochemical processing of organic chemicals has been performed from about the turn 
of the century with production in the early years ${ }^{42}$ of chemicals such as benzidine, sorbitol, mannitol, pinacol, vanillin, hydroquinone, $p$-aminophenol, chloroform, iodoform, chloral, anthraquinone and indigo. Only two chemicals of this list, namely $p$-aminophenol and anthraquinone, have survived to present. However, many new processes have emerged and about 140 have been piloted. At least over 70 are now commercially available worldwide. The electrohydrodimerisation of acrylonitrile to adiponitrile developed by Monsanto in the early 1960's remains the largest volume process. ${ }^{43,44}$ Pletcher and Walsh, ${ }^{18}$ Pütter, ${ }^{6}$ Steckhan ${ }^{7}$ and Degner, ${ }^{8}$ among others, presented an extensive list of commercial and pilot scale electroorganic processes of considerable interest. Here, Table 2 lists examples of recent on-going commercial scale processes, piloted processes which have not reached commercialisation, and processes which had been commercialised but discontinued for various reasons. Significantly, the criteria for success include: $(i)$ higher product selectivity than chemical routes; (ii) lower energy costs; (iii) less expensive/more readily available feedstock; (iv) minimised pollution problems; (v) less hazardous route; $(v i)$ electrochemical route maintains the competitive edge through improved, proprietary technology. In contrast, those electrochemical processes which tend to fail are characterised by one or more of the following: (i) alternative catalytic routes are discovered based upon $\mathrm{H}_{2}$ or $\mathrm{O}_{2}$ (e.g. sorbitol and propylene oxide); (ii) alternative chemical routes are discovered, thereby bypassing an electrochemical intermediate (e.g. pinacol); (iii) the electrochemical product is a pollutant (e.g. tetraalkyl lead) or a carcinogen (e.g. benzidine); (iv) the market vanishes or may not have really existed.

The following compares a few electroorganic processes and highlights the wide range of available possibilities.

\subsubsection{Adiponitrile}

Adiponitrile, an intermediate to nylon, is produced by Monsanto at Decatur, Alabama, to the extent of about 200 million kg per year by electrohydrodimerisation of acrylonitrile, using a cadmium cathode and a steel anode in aqueous phosphate buffer solution in an undivided bipolar cell of compact and sophisticated design (Figure 3). The cathodic reaction is as follows:

$$
2 \mathrm{CH}_{2}=\mathrm{CHCN}+2 \mathrm{H}^{+}+2 \mathrm{e}^{-} \rightarrow \mathrm{NC}\left(\mathrm{CH}_{2}\right)_{4} \mathrm{CN}
$$

Oxygen is produced at the anode. The power is a very significant manufacturing cost component, estimated at $2.4 \mathrm{~kW} \mathrm{~h} \mathrm{~kg}^{-1}$. A 200 million $\mathrm{kg}$ per year plant will, therefore, require power in the order of 50 megawatt.

It is curious that adiponitrile process works at all, because acrylonitrile reduction occurs at a very negative potential compared to those when hydrogen evolution from discharge of water would be expected. Use of a high hydrogen overpotential cathode, $\mathrm{Cd}$, causes the hydrogen evolution reaction to be inhibited and shifted to much more negative potentials. Quaternary ammonium salts, present at low concentration, are strongly adsorbed on the cathode in preference to protons or water and further increase the selectivity for adiponitrile, while operation at high solution concentration of acrylonitrile at near neutral $\mathrm{pH}$ results in yields and current efficiencies approaching 95\%. ${ }^{42-48} \mathrm{It}$ should be remembered that "yield efficiency" stands for the maximum molar amount of desired product obtained from one mole of reactant taking the reaction stoichiometry into account, whereas "current efficiency" refers to the yield based on the electrical charge passed during electrolysis.

\subsubsection{Ethylene glycol}

Ethylene glycol (EG) is produced worldwide at a rate

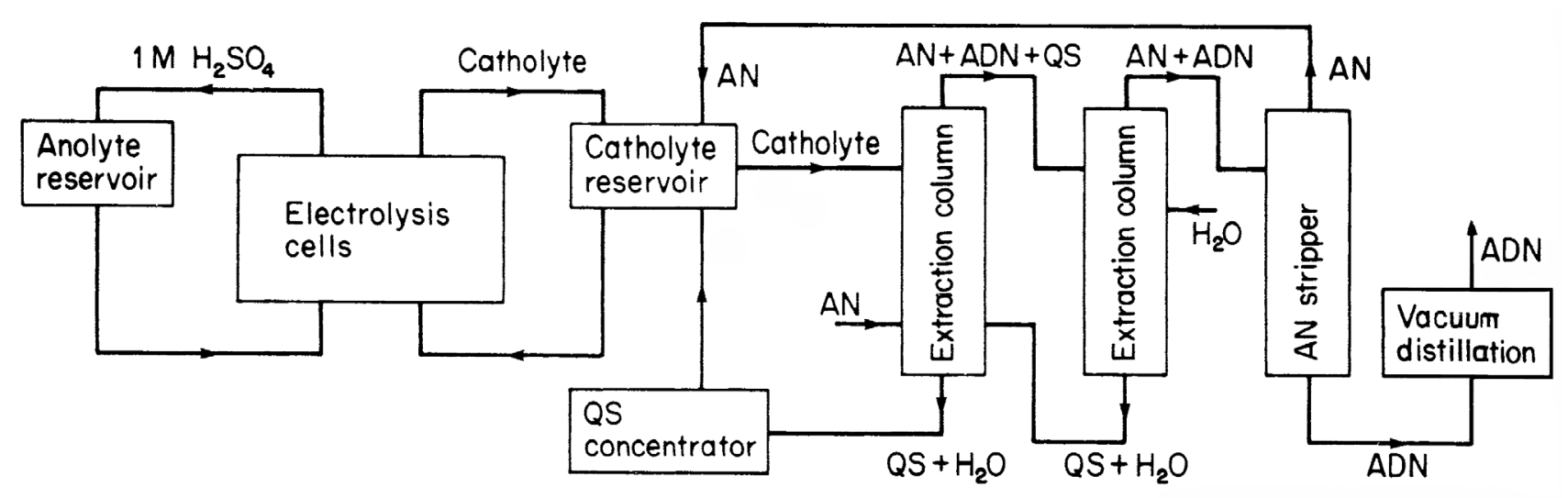

Figure 3. Monsanto flowsheet for the electrohydrodimerisation of acrylonitrile to adiponitrile $(\mathrm{AN}=$ acrylonitrile; $\mathrm{ADN}=$ adiponitrile; $\mathrm{QS}=$ tetraethylammonium ethylsulphate). ${ }^{18}$ Reprinted with kind permission from Springer Science and Business Media. 
Table 2. Examples of industrial organic electrosynthesis processes

\begin{tabular}{|c|c|c|c|}
\hline Product & Starting Material & Company & Operating Status \\
\hline Acetoin & Butanone & BASF & $\mathrm{C}$ \\
\hline 1-Acetoxynaphthalene & Naphthalene & BASF & $\mathrm{P}$ \\
\hline Acetylenedicarboxylic acid & 1,4-Butynediol & BASF & $\mathrm{C}$ \\
\hline Adipoin dimethyl acetal & Cyclohexanone & BASF & $\mathrm{C}$ \\
\hline Adiponitrile & Acrylonitrile & Monsanto (Solutia), BASF, Asahi Chemical & $\mathrm{C}$ \\
\hline 2-Aminobenzyl alcohol & Anthranilic acid & BASF & $\mathrm{P}$ \\
\hline 4-Aminomethylpyridine & 4-Cyanopyridine & Reilly Tar & $\mathrm{C}$ \\
\hline Anthraquinone & Anthracene & L. B. Holliday, ECRC & $\mathrm{C}$ \\
\hline Anthraquinone & Naphthalene, butadiene & Hydro Quebec & $\mathrm{P}$ \\
\hline Arabinose & Gluconate & Electrosynthesis Co. & $\mathrm{P}$ \\
\hline Azobenzene & Nitrobenzene & Johnson Matthey Company & $\mathrm{C}$ \\
\hline Bleached montan wax & Raw montan wax & Clariant & $\mathrm{C}$ \\
\hline 1,2,3,4-Butanetetracarboxylic acid & Dimethyl maleate & Monsanto & $\mathrm{P}$ \\
\hline$p$ - $t$-Butylbenzaldehyde & $p$-t-Butyltoluene & BASF, Givaudan & $\mathrm{C}$ \\
\hline Calcium gluconate & Glucose & Sandoz, India & $\mathrm{C}$ \\
\hline Calcium lactobionate & Lactose & Sandoz, India & $\mathrm{C}$ \\
\hline$S$-Carbomethoxymethylcysteine & Cysteine + chloroacetic acid & Spain & $\mathrm{C}$ \\
\hline Ceftibuten & Cephalosporin C & Electrosynthesis Co., Schering Plough & $\mathrm{P}$ \\
\hline$L$-Cysteine & $L$-Cystine & Wacker Chemie AG & $\mathrm{C}$ \\
\hline Diacetone-2-ketogulonic acid & Diacetone- $L$-sorbose & Hoffman-LaRoche & $\mathrm{C}$ \\
\hline Dialdehyde starch & Starch & CECRI & $\mathrm{C}$ \\
\hline 3,6-Dichloropicolinic acid & 3,4,5,6-Tetrachloro-picolinic acid & Dow & $\mathrm{P}$ \\
\hline 1,4-Dihydronaphthalene & Naphthalene & Clariant & $\mathrm{C}$ \\
\hline 1,2-Dihydrophthalic acid & $o$-Phthalic acid & BASF & $\mathrm{D}$ \\
\hline 2,5-Dimethoxy-2,5-dihydrofuran & Furan & BASF & $\mathrm{C}$ \\
\hline 2,5-Dimethoxy-2,5-dihydrofuryl-1-ethanol & Furfuryl-1-ethanol & Otsuka & $\mathrm{C}$ \\
\hline Dimethylsebacate & Monomethyladipate & Asahi Chemical & $\mathrm{C}$ \\
\hline Ditolyliodonium salts & $p$-Iodotoluene, toluene & Eastman Chemical, Electrosynthesis Co. & $\mathrm{P}$ \\
\hline Ethylene glycol & Formaldehyde & Electrosynthesis Co. & $\mathrm{P}$ \\
\hline Gluconic acid & Glucose & Sandoz, India & $\mathrm{C}$ \\
\hline Glyoxylic acid & Oxalic acid & Rhone Poulenc, Steetley & $\mathrm{P}$ \\
\hline Hexafluoropropyleneoxide & Hexafluoropropylene & Clariant & $\mathrm{C}$ \\
\hline Hexahydrocarbazole & Tetrahydrocarbazole & L. B. Holliday, BASF & $\mathrm{D}$ \\
\hline$m$-Hydroxybenzyl alcohol & $m$-Hydroxybenzoic acid & Otsuka & $\mathrm{C}$ \\
\hline Hydroxymethylbenzoic acid & Dimethyl terephthalate & Clariant & $\mathrm{P}$ \\
\hline$p$-Methoxybenzaldehyde & $p$-Methoxytoluene & BASF & $\mathrm{C}$ \\
\hline 2-Methyldihydroindole & 2-Methylindole & L. B. Holliday, BASF & $\mathrm{D}$ \\
\hline Monochloroacetic acid & tri- and di-Chloroacetic acid & Clariant & $\mathrm{P}$ \\
\hline Mucic acid & Galacturonic acid & $\mathrm{EDF}$ & $\mathrm{C}$ \\
\hline Nitrobenzene & p-Aminophenol & India, Monsanto & $\mathrm{P}$ \\
\hline 5-Nitronaphthoquinone & 1-Nitronaphthalene & Hydro Quebec & $\mathrm{P}$ \\
\hline Partially fluorinated hydrocarbons & Alkanes and alkenes & Phillips Petroleum & $\mathrm{P}$ \\
\hline Perfluorinated hydrocarbons & Alkyl substrates & 3M, Bayer, Clariant & $\mathrm{C}$ \\
\hline Phthalide $+t$-Butylbenzaldehyde acetal & Dimethyl phthalate $+t$-Butyltoluene & BASF & $\mathrm{C}$ \\
\hline Pinacol & Acetone & BASF, Diamond Shamrock & $\mathrm{P}$ \\
\hline Piperidine & Pyridine & Robinson Bros. & $\mathrm{D}$ \\
\hline Polysilanes & Chlorosilanes & Osaka Gas & $\mathrm{C}$ \\
\hline Propiolic acid & Propargyl alcohol & BASF & $\mathrm{P}$ \\
\hline Propylene oxide & Propylene & Kellog, Shell & $\mathrm{P}$ \\
\hline Salicylic aldeyde & $o$-Hydroxybenzoic acid & India & $\mathrm{C}$ \\
\hline Sorbitol & Glucose & Hercules & $\mathrm{D}$ \\
\hline Substituted benzaldehydes & Substituted toluenes & Hydro Quebec, W.R. Grace & $\mathrm{P}$ \\
\hline Succinic acid & Maleic acid & CERCI, India & $\mathrm{C}$ \\
\hline Tetraalkyl lead & Alkyl halide & Nalco & $\mathrm{D}$ \\
\hline 3,4,5-Trimethoxybenzaldehyde & 3,4,5-Trimethoxytoluene & Otsuka Chemical & $\mathrm{C}$ \\
\hline 3,4,5-Trimethoxytolyl alcohol & 3,4,5-Trimethoxytoluene & Otsuka Chemical & $\mathrm{C}$ \\
\hline
\end{tabular}

C - Commercial process; P - Pilot process; D - Discontinued commercial process. 
of about 10 billion $\mathrm{kg}$ per year and, in the USA, at about 3 billion $\mathrm{kg}$ per year by catalytic oxidation of ethylene to ethylene oxide followed by hydrolysis. Major uses are polyethyleneterephthalate (for example, PET bottles and film) and antifreeze. The feedstock for many industrial routes is formaldehyde, which is manufactured by catalytic oxidation of methanol, a syngas-based product. The process of cathodic hydrodimerization of formaldehyde, which is being developed independently by Ontario Hydro Quebec in Canada, generates EG with very high (>98\%) current efficiency in aqueous media at graphite cathodes, according to:

$$
2 \mathrm{CH}_{2} \mathrm{O}+2 \mathrm{H}^{+}+2 \mathrm{e}^{-} \rightarrow \mathrm{HOCH}_{2} \mathrm{CH}_{2} \mathrm{OH}
$$

A number of useful anode processes are, in principle, possible besides oxygen formation, including production of part of the formaldehyde feed from methanol, and terephthalic acid from $p$-xylene electrooxidation. A 200 million $\mathrm{kg}$ per year EG plant (a typical commercial plant size) could have an estimated electric power demand of about 125 megawatt. If this process reaches commercialisation, such a plant will be the third largest sized electrochemical plant, after those for aluminium and chloroalkali. As the adiponitrile electrohydrodimerisation process, the EG process is greatly assisted by the presence of quaternary ammonium salts and operation at nearly neutral $\mathrm{pH}$, of about 5 to 7 . However, whereas adiponitrile can be produced at a large variety of electrode materials, EG is only formed in high yields and current efficiencies at graphite cathodes. It is believed that the surface oxide functionality normally present on carbon takes an active role in the reaction scheme by chemically complexing with formaldehyde. ${ }^{49-54}$

\subsubsection{Anthraquinone}

Anthraquinone (ANQ) and tetrahydroanthraquinone (THAQ) are presently of particular interest as catalysts in pulping operations. British Columbia Research developed an electrochemical route starting with naphthalene, which undergoes electrochemical oxidation to naphthoquinone. The latter is then chemically reacted with butadiene to form THAQ, and THAQ can be converted to ANQ upon further catalytic oxidation. The total estimated THAQ market is 100 million $\mathrm{kg}$ per year if all US and Canadian mills were to adopt this catalyst; however, the price of THAQ needs to be below 3 to $4 € \mathrm{~kg}^{-1}$ to be competitive. ${ }^{55-62}$

British Columbia Research used an anodically regenerable redox couple, namely $\mathrm{Ce}^{4+} / \mathrm{Ce}^{3+}$ in aqueous $\mathrm{H}_{2} \mathrm{SO}_{4}$ to produce the conversion. Chemical oxidation of the naphthalene feed is carried out by $\mathrm{Ce}^{4+}$ outside the cell, with the consequent $\mathrm{Ce}^{4+}$ reduction to $\mathrm{Ce}^{3+}$. This $\mathrm{Ce}^{3+}$ is then oxidised at the anode of the cell regenerating the $\mathrm{Ce}^{4+}$, which would be used to carry out the chemical oxidation of the naphthalene outside the cell. More recently, W.R. Grace has considerably improved the process conditions and economics by using $\mathrm{Ce}^{4+} / \mathrm{Ce}^{3+}$ in aqueous methanesulphonic acid, in which $\mathrm{Ce}^{3+}$ and $\mathrm{Ce}^{4+}$ are much more soluble. This allows operation at higher reaction rates both chemically and electrochemically. ${ }^{63-64}$

The feasibility of a paired electrosynthesis of anthraquinone in a microband electrodes reactor, from the oxidation of anthracene and reduction of dioxygen (Figure 4) has also been attained not long time ago, ${ }^{65}$ opening new avenues in the area of electrolysis in microreactors. ${ }^{17}$

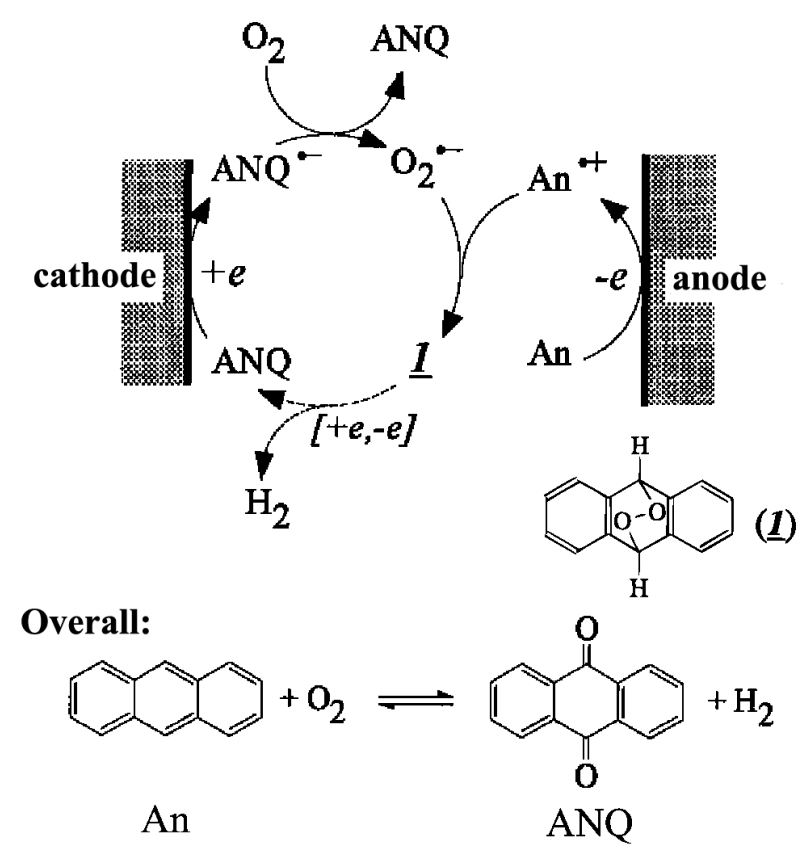

Figure 4. Synthesis of anthraquinone (ANQ) from the oxidation of anthracene (An) and reduction of dioxygen. ${ }^{65}$ Reprinted with permission from Amatore, C.; Brown, A. R.; J. Am. Chem. Soc. 1996, 118, 1482. Copyright (1996) American Chemical Society.

\subsubsection{Perfluorinated products}

The perfluorination of a variety of organic compounds is performed by $3 \mathrm{M}$ using electrolyte solution of anhydrous liquid HF and nickel electrodes in an undivided cell configuration. On polarisation, the anode is believed to form a conductive layer of $\mathrm{NiF}_{6}^{3-}$ which acts here as an insoluble but regenerable fluorinating agent. Hydrogen is produced at the cathode. Perfluorinated carboxylic acids such as perfluorooctanic acid, are amongst the manufactured products. ${ }^{66,67}$

Another method of fluorination using porous carbon anodes was developed by Phillips Petroleum. ${ }^{68,69}$ In this 
version, a melt comprising $\mathrm{KF}-2 \mathrm{HF}$ at about $100{ }^{\circ} \mathrm{C}$ is employed, and the feed is introduced into the body of the porous electrode structure where it permeates to the electrode/electrolyte interface to be fluorinated. Fluorination is believed to occur via fluorine radicals. The products formed include perfluoroalkanes such as perfluorocyclobutane, and perfluorinated carboxylic acids like heptafluorobutyric acid..$^{70-75}$

\subsubsection{Glyoxylic acid}

The electrosynthesis of glyoxylic acid, a synthetic intermediate, from oxalic acid is conducted at a lead cathode in aqueous media without added electrolyte in a membrane separated cell, according to:

$$
\mathrm{HO}_{2} \mathrm{CCO}_{2} \mathrm{H}+2 \mathrm{H}^{+}+2 \mathrm{e}^{-} \rightarrow \mathrm{OHCCO}_{2} \mathrm{H}+\mathrm{H}_{2} \mathrm{O}
$$

The major by-product is glycolic acid. It may be minimised by operating at low temperatures, high flow rates and by using solutions free of trace metal ions. This process is operated commercially by several companies. ${ }^{76-80}$

\subsubsection{L-Cysteine}

The world market for $L$-cysteine is only of the order of 1.5 million $\mathrm{kg}$ per year. The product (selling price $35 €$ to $\left.50 € \mathrm{~kg}^{-1}\right)$ is manufactured electrochemically from $L$-cystine (about $20 € \mathrm{~kg}^{-1}$ ) by various companies including Isochem and Nippon Chemical and Drug. The process is a reductive hydromonomerisation:

$$
\begin{aligned}
\left(\mathrm{SCH}_{2} \mathrm{CH}\left(\mathrm{NH}_{2}\right) \mathrm{CO}_{2} \mathrm{H}\right)_{2}+ & 2 \mathrm{H}^{+}+2 \mathrm{e}^{-} \rightarrow \\
& 2 \mathrm{HSCH}_{2} \mathrm{CH}\left(\mathrm{NH}_{2}\right) \mathrm{CO}_{2} \mathrm{H}
\end{aligned}
$$

Typical cathode materials are $\mathrm{Pb}, \mathrm{Ti}$, stainless steel, $\mathrm{Ni}, \mathrm{Zn}, \mathrm{Ag}$ etc. and the process is run in aqueous $\mathrm{HCl}$ or $\mathrm{H}_{2} \mathrm{SO}_{4}$, in an ion-exchange membrane separated electrolyser. To obtain the free aminoacid, electrodialysis or careful neutralisation of the acid salts must be done in further steps. Some companies have solved the product isolation problem and simplified the overall process by conducting the electrolysis of cystine in aqueous ammonia solution containing no additional electrolyte salt. After electrolysis, the product is separated by evaporation of the solvent, to give cysteine in about $100 \%$ conversion and current efficiency. The aqueous ammonia is reused. ${ }^{81}$

It seems adequate at this point to refer that the initial plan for the present review paper was to cover in retrospect companies with large scale electrolysis, but then it was found more appealing to not only look back but also to look into the future with an optimistic perspective. This explains, in some way, why lab scale methods ${ }^{66,67,70}$ were cited, in addition to large scale installations. ${ }^{81}$

\section{Emerging Electrolytic Processes}

Previous sections covered classical electrosynthetic activity that is well described in the literature. Giving the large amount of available information, and the fact that many technologies are rather old, the approach was simplified, although maintaining a scientific level. Industrial electrosyntheses have met many failures, and besides the research efforts, the emerging of commercial processes is a rather difficult process. For large scale or bulk products manufacture electrochemistry is costly; in fine chemicals preparations the traditional processes, even less selective, are usually better handled by purely chemical processes. In fact, it is not easy to transfer electrons in organic media, but in methanol, acetic acid, dioxane/water and even DMF, among others, electroorganic processes have been described. Moreover, many electrosynthetic processes occur in molten salt environment (for inorganic compounds) or in aqueous media and thus in reactants in some extent water soluble. Improvements in older processes, invention of new ones, and the recent exploration of room-temperature ionic liquid electrolytes and deep eutectic solvents for organic and inorganic electrosynthesis, led to new re-emerging processes that deserve description. That is the case of the electrosynthesis of $\mathrm{N}_{2} \mathrm{O}_{5}$; the discovery of alternative methods for the safe low temperature destruction of organic wastes by means of electrochemical mediators, e.g. $\mathrm{Ag}(\mathrm{II})$; the phthalide / $t$-butylbenzaldehyde paired organic electrosynthesis and the many electrosynthetic processes in ionic liquids.

\subsection{Inorganic synthesis of dinitrogen pentoxide}

$\mathrm{N}_{2} \mathrm{O}_{5}$ is a powerful reagent which can nitrate substances at low temperatures and high reaction rates. ${ }^{82,83}$ By selecting the appropriate solvent system and conditions, a wide range of aliphatic and aromatic compounds can be nitrated. Traditionally, $\mathrm{N}_{2} \mathrm{O}_{5}$ has been prepared by the dehydration of nitric acid using phosphorus pentoxide, ${ }^{84}$ trifluoroacetic anhydride ${ }^{85}$ sulphur trioxide, ${ }^{86}$ or by the oxidation of $\mathrm{N}_{2} \mathrm{O}_{4}$ by ozone. ${ }^{87}$ However, anhydrous $\mathrm{N}_{2} \mathrm{O}_{5}$ can be produced electrochemically in the absence of sulphuric acid, thereby providing a convenient method of nitrating substrates which are sensitive to acidic degradation and/or to the presence of free protons or water.

The electrochemical synthesis of $\mathrm{N}_{2} \mathrm{O}_{5}$ by anodic oxidation of $\mathrm{N}_{2} \mathrm{O}_{4}$ was first reported ${ }^{88}$ in 1910 and since then has been continuously improved. ${ }^{89,90}$ The electrode and cell reactions are as follows: 
Anode: $\mathrm{N}_{2} \mathrm{O}_{4}+2 \mathrm{NO}_{3}^{-} \rightarrow 2 \mathrm{~N}_{2} \mathrm{O}_{5}+2 \mathrm{e}^{-}$

Cathode: $4 \mathrm{HNO}_{3}+2 \mathrm{e}^{-} \rightarrow \mathrm{N}_{2} \mathrm{O}_{4}+2 \mathrm{H}_{2} \mathrm{O}+2 \mathrm{NO}_{3}^{-}$

Overall: $4 \mathrm{HNO}_{3} \rightarrow 2 \mathrm{~N}_{2} \mathrm{O}_{5}+2 \mathrm{H}_{2} \mathrm{O}$

The overall process is dehydration of nitric acid leading to the formation of a solvent with a high $\mathrm{N}_{2} \mathrm{O}_{5}$ concentration. In the past it proved impossible to devise a process which was capable of continuous high conversion of $\mathrm{N}_{2} \mathrm{O}_{4}$ to $\mathrm{N}_{2} \mathrm{O}_{5}$; however, the availability of more stable cell and membrane materials has allowed the process to be developed successfully by the MOD/RARDE (Waltham Abbey, UK). ICI has developed the process on a commercial basis ${ }^{91}$ and tried to offer industrial clients small scale production units, assuming that production of $35 \%$ solutions of $\mathrm{N}_{2} \mathrm{O}_{5}$ would be possible. At present, the re-emerging interest on the electrosynthesis of $\mathrm{N}_{2} \mathrm{O}_{5}$ by $\mathrm{N}_{2} \mathrm{O}_{4}$ oxidation has been maintained due to high utility of $\mathrm{N}_{2} \mathrm{O}_{5}{ }^{.}{ }^{92,93}$

\subsection{Paired organic electrosynthesis}

An excellent example of an innovative industrial organic electrosynthesis process is shown in Scheme 1.

This process was developed at BASF and was described by Hermann Puitter in 1999, at the $13^{\text {th }}$ International Forum on Applied Electrochemistry. This paired 4000 metric ton/ year process produces two valuable products simultaneously with $180 \%$ yield, phthalide $(90 \%)$ and $t$-butylbenzaldehyde dimethylacetal (90\%), by electrolysis in an undivided bipolar capillary gap cell with graphite electrodes.

Other important features of this process are: $(i)$ this is the first commercial example of a paired organic electrosynthesis (useful products are produced both on the anode and on the cathode); (ii) methanol is both a reagent and a solvent: as much methanol is released from reduction of the diester as is consumed in making $t$-butylbenzaldehyde; (iii) current density is 0.1 to $1 \mathrm{kA} \mathrm{m}^{-2}$ at a cell voltage of 4 to 7 volts.
A far larger process range has been proven on a laboratory, or even pilot plant scale but, as has been found elsewhere in the world, development to a commercial production level is the exception rather than the rule. Of the many systems studied worldwide ${ }^{18,94-98}$ only about 100 have been fully or semi-commercialised.

There are several reasons for this low uptake: $(i)$ Poor targeting of appropriate syntheses. Great attention has been devoted to high volume, low added value processes; however, electrochemical processes are often better able to compete in the higher added value low volume area, e.g. pharmaceuticals and speciality chemicals. (ii) Limited ability of the required skills. For successful development of electroorganic processes not only both synthetic organic chemistry and electrochemistry are required for the identification of new processes but also electrochemical engineers who have a knowledge of design criteria and the economics of both the electrochemical and nonelectrochemical aspects of the process. There are only a limited number of locations where all these skills reside together. (iii) Companies not familiar with electrochemistry are reluctant to venture into this area if it is at all possible to use conventional chemistry. (iv) Changes in the market demand for the product. All new processes suffer from this uncertainty but electrochemistry seems particularly prone to this effect. ( $v)$ The inherent cost of electrochemical processes in relation to competing chemical processes and, in many countries, the cost of power.

Experience has, in fact, shown that for small scale, high added value processes, power costs are relatively unimportant. Even so, given the absence of cheap power and the dominance of catalytic chemistry, it may not be surprising that few electroorganic processes have taken off in the world. However, there has been considerable research activity in recent years and the introduction of new processes in ionic liquids, might be expected to definitively revolutionise the industrial electrosynthesis in the next decades.

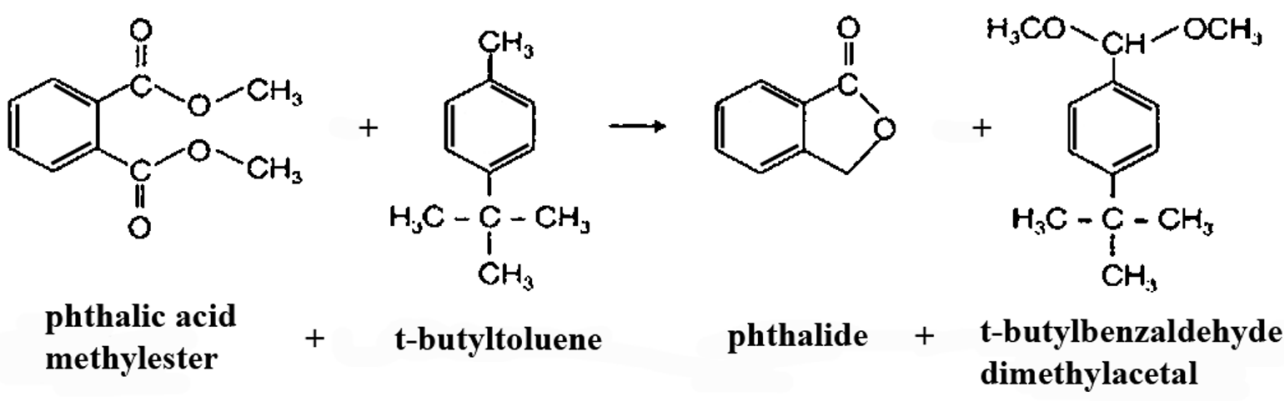

Scheme 1. Industrial paired organic electrosynthesis process for simultaneous production of phthalide and $t$-butylbenzaldehyde dimethylacetal. Copied by permission from the "Electrochemistry Encyclopedia" (http://electrochem.cwru.edu/ed/encycl/) accessed on October/31/2008. The original material is subject to periodical changes and updates. 


\subsection{Inorganic synthesis in ionic liquids}

Ionic liquids are not new; some of them have been known for many years, for instance $\left[\mathrm{Et}^{\mathrm{N}} \mathrm{NH}_{3}\right] \cdot\left[\mathrm{NO}_{3}\right]$, which has a melting point of $12{ }^{\circ} \mathrm{C}$, was first described in $1914 .{ }^{99}$ The early history of ionic liquid research was dominated by their application as electrochemical solvents. One of the first recognised uses of ionic liquids was as a solvent system for the room temperature electrodeposition of aluminium. ${ }^{100}$ In addition, much of the additional development of ionic liquids was focused on their use as electrolytes for battery and capacitor applications. ${ }^{101}$ Chemical and electrochemical studies on the ionic liquids have until recently been dominated by work in the room-temperature haloaluminate molten salts. ${ }^{102-106}$ Development of non-haloaluminate ionic liquids over the past fifteen years has resulted in an explosion of research in these systems. ${ }^{107-117}$ In particular, the application of these "new" ionic liquids in useful electrochemical reactions including the Kolbe oxidation, the reductive alkene coupling and carbonylation, and alkyl halide coupling, among others, is well illustrated in the literature. ${ }^{118-124}$

Ionic liquids possess a variety of properties (low melting point, non-volatility, high ion density, high ion conductivity etc) that make them desirable as electrolytes for electrochemical devices and processes, solvents for organic and catalytic reactions, new material production, solvents for separation and extraction processes etc.

Besides their very low vapour pressure which makes ionic liquids good alternative solvents to volatile organic solvents, they display a large operating range (typically from $-40{ }^{\circ} \mathrm{C}$ to $200{ }^{\circ} \mathrm{C}$ ), a good thermal stability, ${ }^{125}$ high ionic conductivity, ${ }^{126,127}$ large electrochemical window, ${ }^{126}$ that is, large electroactivity domain, and solvent transport properties. ${ }^{128,129}$ However, the key property of these liquids is the possibility to tune their physical and chemical properties by varying the nature of the cations and anions. ${ }^{130,131}$ The spectrum of their physical and chemical properties is much larger than that of organic solvents. Some typical physical characteristics of currently used salts are given in Table 3.
It should be noted at this stage that the physical and chemical properties of ionic liquids can be largely altered by the presence of impurities arising from its preparation, ${ }^{132,133}$ and therefore purification is essential.

Solvent polarity has often a strong influence on the outcome of reactions. However, the exact meaning of "polarity" is already complex, but even more complicated in the case of ionic solvents, as many interactions can be involved. Different investigations of solvent-solute interactions in ionic liquids using solvatochromic dyes have been reported. ${ }^{134,135}$ This is in agreement with the ionic liquid solvent effect described in the Diels-Alder reactions of cyclopentadiene with methyl acrylate. ${ }^{136}$ The endo/ exo selectivity, which may be viewed as being dependent on the polarity of the solvent, is high $(6.1: 1)$ when using $[\mathrm{BMIM}] \cdot\left[\mathrm{BF}_{4}\right]$ ([BMIM] = 1-butyl-3-methylimidazolium), and compares quite well to that obtained with methanol (6.7:1). These selectivities are characteristic of hydrogenbonded, polar organic solvents.

The ionic liquid nucleophilicity ${ }^{137}$ is only anion dependent and much lower than that of polar solvents which makes ionic liquids unique. This degree of coordination has been correlated to solvent effect observed in Ni catalysed oligomerisation of ethylene. ${ }^{138}$

Apart from the properties already discussed, the ionic liquids are non-flammable materials. The nonflammable liquids with high ionic conductivity and inherent non-volatility are practical materials for use in electrochemistry.

The main concern here is to assess some possible uses of ionic liquids in electrochemical synthesis. Inorganic electrosynthesis will be dealt in the present section. The next section will deal specifically with organic electrosynthesis.

The majority of electrosyntheses of inorganic materials consists on the electrodeposition of metals, alloys and semiconductors from ionic liquids. Not only could technical procedures and devices profit, but interesting insights into the nanoscale processes during electrodeposition of elements such as germanium, silicon etc, are also possible, especially for semiconductor nanostructures that will be

Table 3. Some physical characteristics of currently used 1-butyl-3-methylimidazolium ionic liquids

\begin{tabular}{lcccc}
\hline Anion & $\mathrm{mp} /\left({ }^{\circ} \mathrm{C}\right)$ & Density $/\left(\mathrm{g} \mathrm{cm}^{-3}\right)$ & Viscosity/(cP) & Conductivity/(S m$\left.{ }^{-1}\right)$ \\
\hline $\mathrm{BF}_{4}^{-}$ & $-82 /-83$ & $1.17\left(30^{\circ} \mathrm{C}\right)$ & $233\left(30^{\circ} \mathrm{C}\right)$ & $0.173\left(25^{\circ} \mathrm{C}\right)$ \\
$\mathrm{PF}_{6}^{-}$ & -61 & $1.37\left(30{ }^{\circ} \mathrm{C}\right)$ & $312\left(30{ }^{\circ} \mathrm{C}\right)$ & $0.146\left(25^{\circ} \mathrm{C}\right)$ \\
$\mathrm{CF}_{3} \mathrm{SO}_{3}^{-}$ & 16 & $1.290\left(20^{\circ} \mathrm{C}\right)$ & $90\left(20^{\circ} \mathrm{C}\right)$ & $0.37\left(20^{\circ} \mathrm{C}\right)$ \\
$\mathrm{CF}_{3} \mathrm{CO}_{2}^{-}$ & $-50 /-30$ & $1.209\left(21^{\circ} \mathrm{C}\right)$ & $73\left(20^{\circ} \mathrm{C}\right)$ & $0.32\left(20^{\circ} \mathrm{C}\right)$ \\
$\mathrm{NTf}_{2}^{-}$ & -4 & $1.429\left(19^{\circ} \mathrm{C}\right)$ & $52\left(20^{\circ} \mathrm{C}\right)$ & $0.39\left(20^{\circ} \mathrm{C}\right)$ \\
\hline
\end{tabular}


important in nanotechnology. Examples pertaining to the electrodeposition of metals and alloys in ionic liquids based on organic cations, are listed below. Figure 5 shows the formal potentials of some redox couples in chloroaluminate ionic liquids. ${ }^{215}$

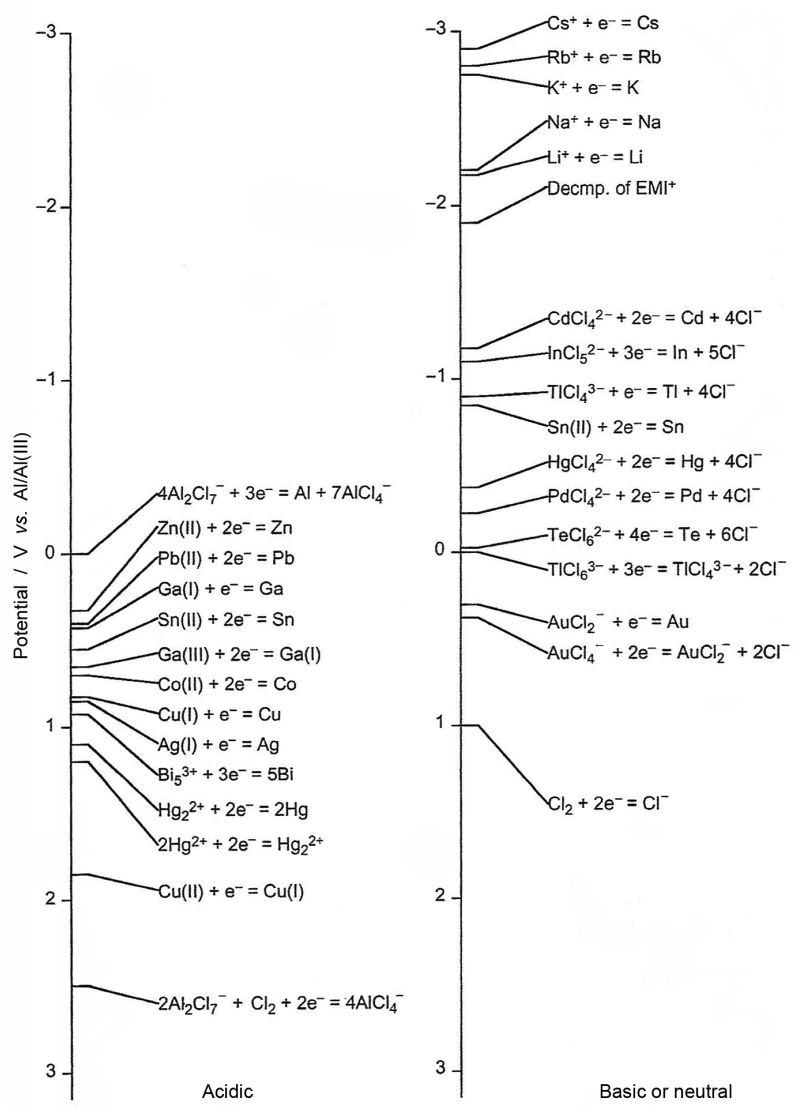

Figure 5. Formal potentials of some redox couples in the chloroaluminate ionic liquids. ${ }^{215}$ This material is reproduced with permission of John Wiley \& Sons, Inc.

In this figure, the potentials are given in relation to the $\mathrm{Al} / \mathrm{Al}(\mathrm{III})$ electrode. This electrode is composed of $\mathrm{Al}$ immersed in an acidic ionic liquid of 66.4 or $60.0 \mathrm{~mol} \%$ $\mathrm{AlCl}_{3}$. All the indicated metals can be electrodeposited as pure metals or alloys in the acid (or basic) chloroaluminate liquid. ${ }^{139-152}$ The electrodeposition of several metals and alloys has also been investigated in tetrafluoroborate $\left(\mathrm{BF}_{4}^{-}\right)$, hexafluorophosphate $\left(\mathrm{PF}_{6}^{-}\right)$and chlorozincate ionic liquids. ${ }^{153-158}$ These liquids are less reactive against water than the chloroaluminate ionic liquids.

Most of the ionic liquids melting at low temperature are composed of alkylated imidazolium cations, and there is no good explanation of why the melting point and viscosity become lower in the presence of these imidazolium cations. However, the cathodic stability of the imidazolium cations is not sufficient for the electrodeposition of the base metals, which have not been obtained in roomtemperature ionic liquids. It has been shown that many kinds of room-temperature ionic liquids can be prepared by combining various quaternary ammonium cations with

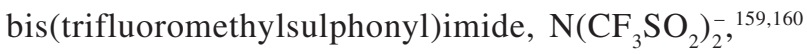
and these are being used for the electrodeposition of lithium and other metals. ${ }^{161,162}$ The electrodeposition of $\mathrm{Ga}$, Ga-As, In-Sb, Sn, Nb-Sn etc, has been reported in many other ionic liquids. ${ }^{163-165}$

Work by Stickney, ${ }^{166}$ has shown that electrochemical atomic layer epitaxy (ECALE) in aqueous media is a suitable deposition method for compound semiconductors with qualities comparable to those made by vacuum techniques. In special electrochemical polarisation routines, the elements of a compound semiconductor are successively deposited one onto the other, layer-bylayer. Unfortunately, direct electrodeposition of CdTe, $\mathrm{CdSe}$, and others is difficult for kinetic reasons, and in many cases the elements are codeposited together with the desired semiconductor in varying amounts at room temperature. Variation of the temperature can strongly affect the quality of the electrodeposits. ${ }^{167}$ In general, direct electrodeposition of a compound semiconductor would be interesting as it would be less time-consuming than the elegant ECALE process. Although there are only a few articles on semiconductor electrodeposition from ionic liquids, these media are interesting for such studies for several reasons: the acidity can be varied over wide ranges, they have low vapour pressures, and as a consequence depending on the system - the temperature can be varied over several hundred degrees, so that kinetic barriers in compound formation can be overcome. Furthermore, because of the wide electrochemical windows, it is possible to obtain compounds that are inaccessible from aqueous solutions, one example being GaAs. For GaSb, InSb, InP, and ternary compound semiconductors, electrodeposition from ionic liquids could be interesting, especially if higher temperatures were applied. As compound semiconductors, elemental semiconductors can also be obtained from ionic liquids. Si and Ge are widely used as wafer material for different electronic applications, and junctions of $\mathrm{n}$ - and p-doped $\mathrm{Si}$ are still interesting for photovoltaic applications. Controlled electrodeposition of both elements and their mixtures would also surely be attractive for nanotechnology, as Ge quantum dots made under UHV conditions show interesting photoluminescence. ${ }^{154,155,165,168-171}$

In situ scanning tunnelling microscope studies on electrochemical phase formation from ionic liquids were also started about ten years ago. Aluminium, copper, and germanium electrodepositions on Au (111), are some successful examples. ${ }^{154,155,172,173}$ 
Apart from the described electrodepositions in ionic liquids, other inorganic compounds are being synthesised electrochemically in ionic liquids. It is the case, for example, of the electrosynthesis of hydrogen peroxide from oxygen in 3-butyl-methylimidazolium tetrafluoroborate. ${ }^{174} \mathrm{H}_{2} \mathrm{O}_{2}$ can be subsequently used for the epoxidation of alkenes. The whole process can be regarded as a totally clean system as only oxygen, water and electricity are required.

\subsection{Organic synthesis in ionic liquids}

When ionic liquids are used as electrolytic media, organic electrolytic reactions, particularly electroorganic synthesis should be possible without any organic solvents. This section covers the applications of ionic liquids to organic electrolytic reactions, particularly organic electrosynthesis. ${ }^{175,176}$

Anodic partial fluorination, namely selective anodic fluorination of organic compounds, has much importance in the development of new types of pharmaceuticals, agrochemicals, and functional materials. However, the selective fluorination is not straightforward, and it very often requires hazardous reagents. Still selective anodic fluorination seems to be an ideal method because it can be carried out under mild conditions without any hazardous and/or reagents. ${ }^{177,178}$ The fluorination is usually conducted in aprotic solvents containing HF salt ionic liquids such as $\mathrm{Et}_{3} \mathrm{~N} \cdot 3 \mathrm{HF}$ and $\mathrm{Et}_{4} \mathrm{NF} \cdot 3 \mathrm{HF}$. Since the discharge potential of fluoride ions is extremely high $(>2.9 \mathrm{~V} v s$. SCE at Pt anode in $\mathrm{MeCN}$ ), the fluorination proceeds via a (radical) cation intermediate as shown in Scheme 2:

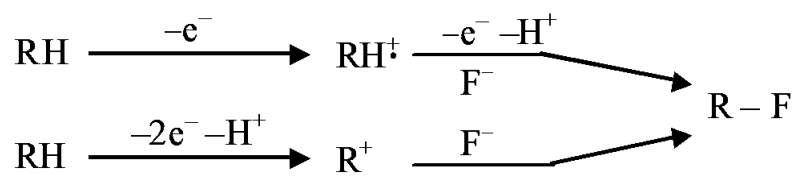

Scheme 2. Anodic fluorination of organic compounds via a (radical) cation intermediate.

When organic solvents are used for anodic fluorination, anode passivation (the formation of a nonconducting polymer film on the anode surface that suppresses faradic current) takes place very often, which results in low efficiency. Moreover, depending on the substrates, the use of acetonitrile can yield an acetoamidation by-product. To prevent acetoamidation and anode passivation, Meurs and his co-workers used an $\mathrm{Et}_{3} \mathrm{~N} \cdot 3 \mathrm{HF}$ ionic liquid as both a solvent and supporting electrolyte (also a fluorine source) for the anodic fluorination of benzenes, naphthalene, olefins, furan, benzofuran, and phenanthroline. ${ }^{179}$

Fuchigami's group and Laurent's group have independently achieved anodic $\alpha$-fluorination of $\alpha$-phenylthioacetate (1) in $\mathrm{Et}_{3} \mathrm{~N} \cdot 3 \mathrm{HF} / \mathrm{MeCN} .^{180,181}$ Since anode passivation takes place during the anodic fluorination, pulse electrolysis is necessary to avoid the anode passivation. Anodic difluorination of $\mathbf{1}$ was unsuccessful in the same electrolyte solution, while anodic fluorination of $\alpha$-monofluorinated acetate (2) gave the $\alpha, \alpha$-difluorinated product (3) in moderate yield after passing a large excess amount of electricity (Scheme 3): ${ }^{182}$

Momota and co-workers ${ }^{183}$ developed a new series of liquid fluoride salts, $\mathrm{R}_{4} \mathrm{NF} . n \mathrm{HF}(\mathrm{R}=\mathrm{Me}$, Et, and $n-\mathrm{Pr}, n>3.5)$, that are useful in partial fluorination. These electrolytes are non viscous liquids that have high electroconductivity and anodic stability (Figure 6). As a result, anodic partial fluorination of arenes such as benzene, ${ }^{183}$ mono-, di- and tri-fluorobenzenes, ${ }^{184}$ chlorobenzene, ${ }^{185}$ bromobenzene, ${ }^{186}$

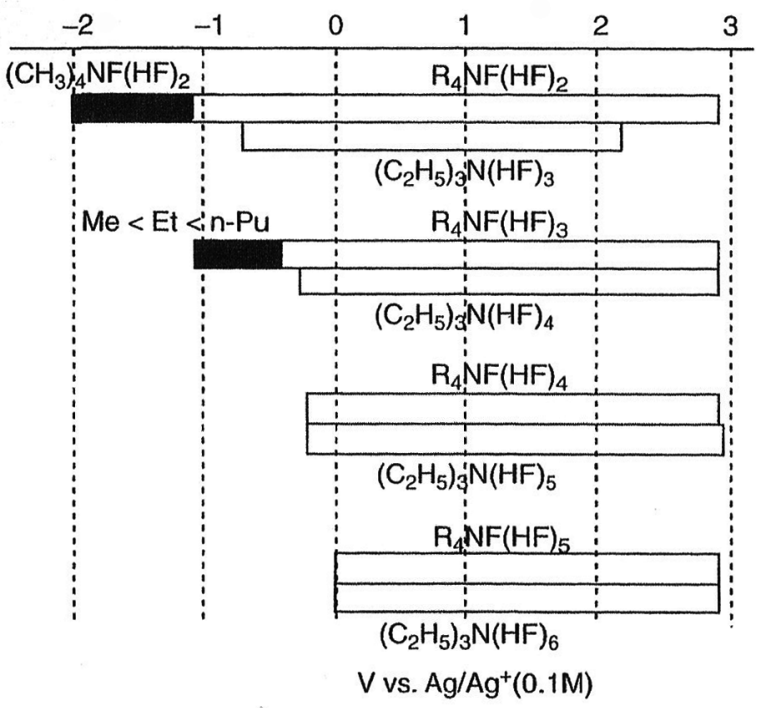

Figure 6. Potential windows of fluoride ionic liquids. ${ }^{215}$ This material is reproduced with permission of John Wiley \& Sons, Inc.

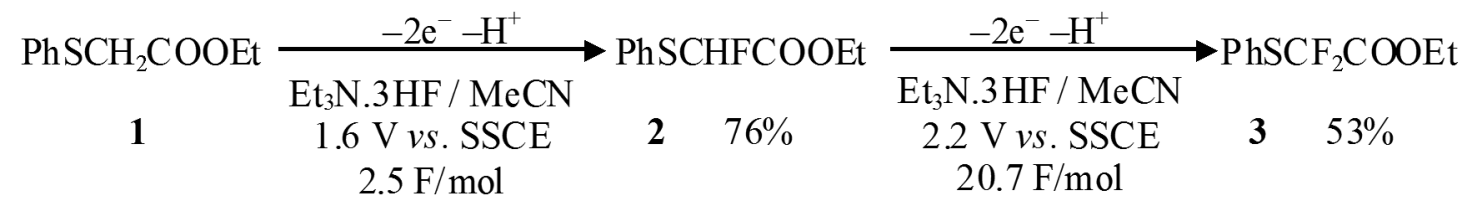

Scheme 3. Anodic $\alpha$-fluorination of $\alpha$-phenylthioacetate (1) in $\mathrm{Et}_{3} \mathrm{~N} .3 \mathrm{HF} / \mathrm{MeCN}$ to $\alpha, \alpha$-difluorinated phenylthioacetate (3). ${ }^{182}$ Reprinted with permission from Fuchigami, T.; Shimojo, M; Konno, A.; J. Org. Chem. 1995, 60, 3459. Copyright (1995) American Chemical Society. 


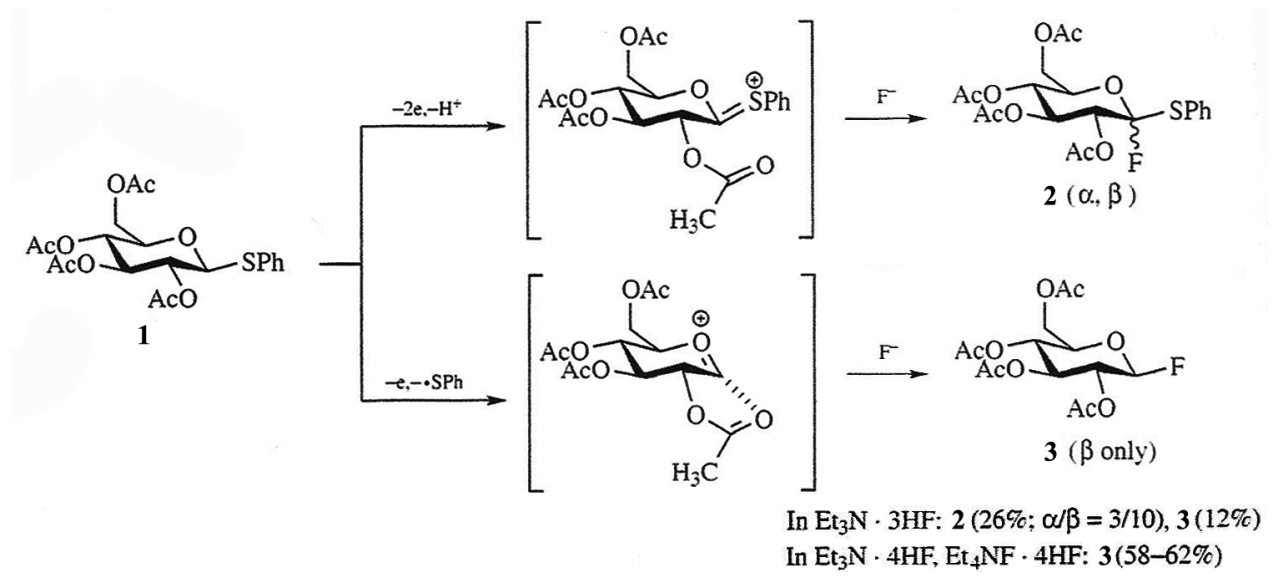

Scheme 4. Electrolysis of phenylthioglycoside derivative $\mathbf{1}$ in $\mathrm{Et}_{3} \mathrm{~N}-3 \mathrm{HF}$ to yield $\alpha$-fluorinated product $\mathbf{2}$ along with $\mathbf{3}$, and that in $\mathrm{Et}_{3} \mathrm{~N} \cdot 4 \mathrm{HF}, \mathrm{Et}_{4} \mathrm{NF} \cdot 4 \mathrm{HF}$ to provide fluorodesulphurisation product $\mathbf{3}$ exclusively. ${ }^{215}$ This material is reproduced with permission of John Wiley \& Sons, Inc.

toluene, ${ }^{187,188}$ and quinolines ${ }^{189}$ was successfully carried out at high current densities by employing these liquid fluoride salts in the absence of solvent with good to high current efficiencies (66-90\%). In summary, several fluoride ionic liquids can be useful, as they allow higher current densities than usual ionic liquids and offer a unique access to fluorinated products or fine chemicals.

Fuchigami and his co-workers ${ }^{190}$ found that the fluorination of cyclic ethers like tetrahydrofuran, 1,4-dioxane, and 1,3-dioxolane was achieved by anodic oxidation of a mixture of a large amount of liquid cyclic ethers and a small amount of $\mathrm{Et}_{4} \mathrm{NF} .4 \mathrm{HF}$ (only 1.5-1.7 equiv. of $\mathrm{F}^{-}$to the ether) at high current density $\left(150 \mathrm{~mA} \mathrm{~cm}^{-2}\right)$.

Moreover, Fuchigami's group found that a combination of $\mathrm{Et}_{4} \mathrm{NF} . n \mathrm{HF}(n: 4,5)$ and imidazolium ionic liquids was highly effective for anodic fluorination of phthalides. ${ }^{191}$

It has been shown recently that anodically fluorinated product selectivity is greatly affected by fluoride ionic liquids. ${ }^{192}$ The electrolysis of a phenylthioglycoside derivative $\mathbf{1}$ in $\mathrm{Et}_{3} \mathrm{~N}-3 \mathrm{HF}$ affords $\alpha$-fluorinated product $\mathbf{2}$ along with 3, while that in $\mathrm{Et}_{3} \mathrm{~N} \cdot 4 \mathrm{HF}, \mathrm{Et}_{4} \mathrm{NF} \cdot 4 \mathrm{HF}$ provides fluorodesulphurisation product 3 exclusively. Since $\mathrm{Et}_{3} \mathrm{~N} \cdot 3 \mathrm{HF}$ contains a considerable amount of free $\mathrm{Et}_{3} \mathrm{~N}$, $\mathrm{Et}_{3} \mathrm{~N}$ seems to accelerate deprotonation of the radical cation intermediate resulting in the formation of $\alpha$-fluorinated product 2 (Scheme 4).

The direct or Ni-catalysed electroreductive homocoupling of organic halides and couplings of organic halides with activated olefins were efficiently conducted by constant current electrolysis in an undivided cell at room temperature ionic liquids as the solvent-electrolyte media. ${ }^{193}$

Recently Martiz et al. ${ }^{194}$ described the electrosynthesis of functionalised siloxanes that were produced selectively in good isolated yields. Scheme 5 shows three examples of electrogenerated diorganilsilanones.

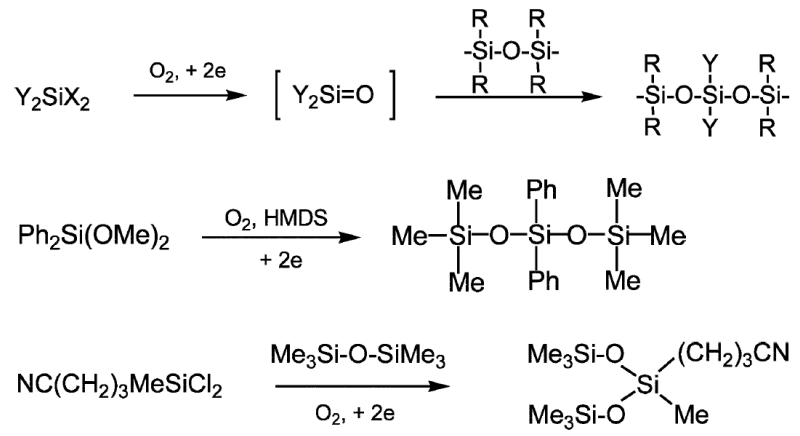

Scheme 5. Examples of electrogenerated diorganilsilanones produced selectively in good yields. ${ }^{215}$ This material is reproduced with permission of John Wiley \& Sons, Inc.

The electrochemical synthesis and characterisation of poly(3,4-ethylenedioxythiophene) in ionic liquids with bulky organic anions is described by Danielsson et al. ${ }^{195}$ They observed that the ionic transport properties of the polymer film were strongly influenced by the water content of the ionic liquid.

The electrochemical reduction of benzaldehyde at Pt microelectrodes in 1-butyl-1-methyl pyrrolidinium triflimide is reported by Doherty and Brooks. ${ }^{196}$

The electrochemical oxidation of mononuclear (anisole, mesitylene) and fused polynuclear (naphthalene, anthracene) aromatic compounds was performed in various ionic liquids ${ }^{197}$ to provide the products of anodic dimerisation. Under similar conditions, the process with 1,2-dimethoxy-benzene resulted in polyveratrole, stable blue-coloured doped polymer of amorphous or fibrillar morphology depending on the ionic liquid used as the electrolyte media.

Mattes' group and Fuchigami's group achieved independently electrooxidative polymerisation of pyrrole, thiophene, and aniline in different moisture stable 
imidazolium ionic liquids. ${ }^{198-200}$ Mattes' group used 1-butyl-3-methylimidazolium tetrafluoroborate and hexafluorophosphate ([BMIM] $\left[\mathrm{BF}_{4}\right]$ and $[\mathrm{BMIM}] \cdot\left[\mathrm{PF}_{6}\right]$ ) for electropolymerisation, and they found that $\pi$-conjugated polymers thus obtained are highly stable and that they can be electrochemically cycled in the ionic liquids up to million cycles. In addition, since the polymers have cycle switching speeds as fast as $100 \mathrm{~ms}$, they can be used as electrochemical actuators, electrochromic windows, and numeric displays.

Fuchigami and co-workers employed [EMIM].[OTf] (1-ethyl-3-methylimidazolium trifluoromethanesulphonate) for the electropolymerisation. They found that the polymerisation of pyrrole in the ionic liquid proceeds much faster than that in conventional media like aqueous and acetonitrile solutions containing $0.1 \mathrm{~mol} \mathrm{~L}^{-1}$ [EMIM]-[OTf] as supporting electrolyte.

It is known that in the radical-radical coupling, further oxidation of oligomers and polymer deposition in the electrooxidative polymerisation are favourably affected because the reaction products are accumulated in the vicinity of the electrode surface under slow diffusion conditions, and consequently the polymerisation rate is increased. It is reasonable to assume that the polymerisation rate in [EMIM] [OTf] is higher than that in the conventional media, since neat [EMIM] [OTf] (viscosity: $42.7 \mathrm{cP}$ ) has a higher viscosity than the others. Electropolymerisation of thiophene is also accelerated in this ionic liquid, whereas that of aniline is decelerated.

The polymer films prepared in this ionic liquid have also a higher electrochemical density and highly regulated morphological structures. Therefore, their possible utilisations are as high-performance electrochemical capacitors, ion-sieving films, ion-selective electrodes, matrices for hosting catalyst particles, and so on.

Other electropolymerisations described in the open literature are the electrosynthesis of polyphenylenediamine in 1-ethyl-3-methylimidazolium bromide and N-methylimidazolium tetrafluoroborate, ${ }^{201}$ the electrosynthesis of poly(o-phenylenediamine) in N-butyl$\mathrm{N}$-methylpyrrolidinium (nonafluorobutane-sulphonyl)(trifluoromethanesulphonyl) imide, ${ }^{202}$ and the electrosynthesis of polyaniline in 1-butyl-3-methyl-imidazolium. ${ }^{203}$

Deng and co-workers ${ }^{204}$ found that $\mathrm{CO}_{2}$ was reduced at a copper cathode at $-2.4 \mathrm{~V} v$ s. $\mathrm{Ag} / \mathrm{AgCl}$. They successfully prepared cyclic carbonates by the reduction of $\mathrm{CO}_{2}$ in the presence of epoxides in various ionic liquids like [BMIM]. $\left[\mathrm{BF}_{4}\right]$ (1-butyl-3-methylimidazolium tetrafluoroborate), [BMIM]·[PF $\left.{ }_{6}\right]$ (1-butyl-3-methylimidazolium hexafluorophosphate), and $[\mathrm{BPy}] \cdot\left[\mathrm{BF}_{4}\right]$ (N-butylpyridinium tetrafluoroborate) using a $\mathrm{Cu}$ cathode and $\mathrm{Mg}$ or $\mathrm{Al}$ anode. This electrolysis in a non-faradic reaction in which a small amount of electricity engaged in the electroreduction of $\mathrm{CO}_{2}$ generates catalytic species responsible for the addition of $\mathrm{CO}_{2}$ in epoxides to form cyclic carbonates.

Jouikov and his co-workers ${ }^{205}$ reported the electrocatalytic homo-coupling of $\mathrm{PhBr}$ and $\mathrm{PhCH}_{2} \mathrm{Br}$ using $\mathrm{NiCl}(\mathrm{BPy})$ complex in [BMIM][ $\left.\mathrm{NTf}_{2}\right]$ (1-butyl-3-methylimidazolium bis[(trifluoromethyl)sulphonyl]amide).

Barhdadi and his co-workers ${ }^{206}$ have found that direct electroreductive coupling of organic halides in [Octyl-MIM]·[BF 4 (1-octyl-3-methylimidazolium tetrafluoroborate) was unsuccessful because of its high viscosity. However, they successfully carried out the reaction in the ionic liquid containing DMF (10\% v/v) using a $\mathrm{Ni}$ cathode and $\mathrm{Mg}$ or $\mathrm{Al}$ anode.

$\mathrm{Lu}$ and his co-workers reported the electroreduction of benzylformic acid at a glassy carbon cathode and $\mathrm{Pt}$ anode in ionic liquid [EMIM] $[\mathrm{Br}]$ at $80^{\circ} \mathrm{C}$ giving mandelic acid in high yield and with moderate current efficiency. ${ }^{207}$

Other developments are described in the literature, ${ }^{208}$ and given that the organic electrochemistry in ionic liquids is being recognised as a green and sustainable chemistry, it can be easily expected great developments in electrosynthesis using these remarkable materials.

\subsection{State of commercial activity}

Significant electrosynthesis of organic chemicals occur only at a few sites in the world. It is believed that there may well be more processes in the pipeline, but this area is particularly difficult due to commercial concern over publication of this information. Here are reviewed four sites in the UK where relevant activity is underway.

\subsubsection{BASF plc}

In the mid 1970's, Monsanto built a plant at Seal Sands for adiponitrile production from acrylonitrile by electrohydrodimerisation. BASF took over the plant ownership in 1985. The plant capacity is 90 million $\mathrm{kg}$ per year but the actual production figure is not available. The acrylonitrile is prepared on site from propylene and ammonia and the electrohydrodimerisation to adiponitrile takes place in an undivided parallel-plate cell with a cadmium cathode and a stainless steel anode. The cell design is a product of Monsanto technology and is described in more detail elsewhere. ${ }^{18,96}$ The electrode reactions are as follows:

Cathode: $2 \mathrm{CH}_{2} \mathrm{CHCN}+2 \mathrm{H}_{2} \mathrm{O}+2 \mathrm{e}^{-} \rightarrow$

Anode: $2 \mathrm{H}_{2} \mathrm{O} \rightarrow \mathrm{O}_{2}+4 \mathrm{H}^{+}+4 \mathrm{e}^{-}$

Overall: $2 \mathrm{CH}_{2} \mathrm{CHCN}+\mathrm{H}_{2} \mathrm{O} \rightarrow\left(\mathrm{CH}_{2} \mathrm{CH}_{2} \mathrm{CN}\right)_{2}+1 / 2 \mathrm{O}_{2}$ 
The adiponitrile is further reduced on site by catalytic hydrogenation to hexamethylenediamine, a starting material for nylon-6,6 manufacture.

BASF have reconfirmed their interest in this area by recently upgrading their research facility at Seal Sands.

\subsubsection{INEOS (Runcorn)}

INEOS have made a considerable commitment to the identification of commercial electroorganic processes using their FM01/FM21 cell technology. Bench scale studies are carried out with smaller FM01 cell for which a range of electrode materials are available. Carbon is a notable omission but this is now available in the relatively recent FB01 bipolar stack cell configuration. A larger FB20 cell $\left(0.2 \mathrm{~m}^{2}\right)$ has been designed for production purposes.

Szánto et al. ${ }^{209}$ used the FM01-LC INEOS electrolyser to evaluate the electrosynthesis of coumestan and catecholamine derivatives on several reticulated vitreous carbon (RVC) electrodes. The performance of 30, 60 and 100 ppi (nominal pores per linear inch) RVCs was compared with that of porous three dimensional nickel electrodes. Both 30 and 60 ppi RVCs were found to perform indifferently, while the 100 ppi RVC had a performance comparable to the nickel stacked net. Conversion efficiencies for the oxidation of cathecol were assumed $80 \%$. Yields for the production of coumestan and cathecolamine were approximately $45 \%$ and $25 \%$, respectively, although this was mostly due to extraction problems, since current efficiencies were both in the region of $65-70 \%$.

As a result of INEOS continuous effort, several processes have been proven to be technically successful and have been operated on a pilot plant scale up to 1 tonne per year. That is the case of the electroorganic processes shown in Scheme 6.

Commercial production has not taken place because of (i) changes in the market for the product; (ii) failure at a non-electrochemical stage of a multi-step synthesis; or (iii) the temporary mothballing of the process for internal reasons. In spite of this, INEOS believes that new processes producing in excess of 500 tonnes per year (including $\mathrm{N}_{2} \mathrm{O}_{5}$ production) can be expected within the next five years.

\subsubsection{ERDC (Capenhurst) / Electrocatalytic Inc.}

Electroorganic processes have also been developed by the ECRC and, in some cases, commercialised under license by Electrocatalytic Inc. (Gwent) for industrial clients. A list of electroorganic processes developed successfully at a laboratory stage is shown in Table 4, although little information is available on these projects.

Table 4. Laboratory scale processes developed by ERDC (Capenhurst)

\begin{tabular}{ll}
\hline Product & Method $^{\mathrm{a}}$ \\
\hline Benzoquinone & Direct oxidation \\
Menadione & Indirect oxidation \\
Naphthoquinone & Indirect oxidation \\
Anisaldehyde & Indirect oxidation \\
$p$-Nitrobenzoic acid & Indirect oxidation \\
Dimethoxidihydrofuran & Anodic substitution \\
2-Methylindolene & Direct reduction \\
Glyoxylic acid & Direct reduction \\
$L$-Cysteine & Direct reduction \\
Dicarboxyphenylsulphone & Indirect oxidation - Cr(VI) \\
Dicarboxyphenylether & Indirect oxidation - Cr(VI) \\
Tolualdehyde & Indirect oxidation - Mn(III) \\
\hline
\end{tabular}

${ }^{a}$ Due to confidential issues no further information is available.

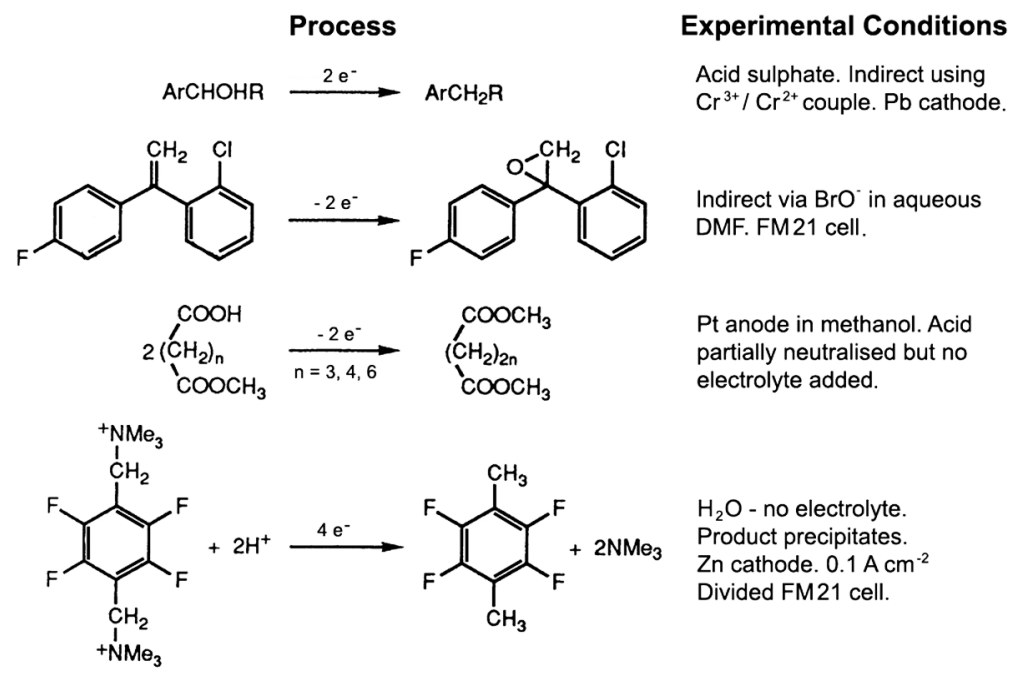

Scheme 6. INEOS electroorganic processes operated on a pilot plant scale up to 1 tonne per year. 


\subsubsection{Synprotec (Manchester)}

Synprotec undertakes research contracts on electrochemical processes for industrial clients predominantly from Europe and North America rather than the UK. Their pilot plant consists of an Electrocatalytic DEM cell of up to $1 \mathrm{~m}^{2}$ which can be operated with a variety of materials. No details of the processes concerned can be released but indirect oxidations are of particular interest and $p$-methoxytoluene has been successfully converted to $p$-methoxybenzaldehyde (anisaldehyde). The removal of organic contaminants from aqueous streams using electrochemical oxidation is also topical.

\section{A Summary of Technological Advances}

Laboratory and industrial electrosynthesis has experienced unprecedented growth over the past three decades because of major advances in electrode materials, membranes, electrolytes and electrolysers. ${ }^{17,210-212}$ The chloroalkali industry entered the 1960's somewhat content with relatively "low-tech" diaphragm cell improvements such as inert moulded plastic cell tops (instead of concrete), somewhat longer duration graphite anodes (about 6 months), and more energy efficient cells. By 1970 , the industry awoke to noble metal catalysed titanium electrodes, so-called "dimensionally stable anodes", which could last for several years, could generate chlorine uncontaminated by halocarbons, and could provide impressive energy savings because they could operate at very low overpotential (i.e. at a small difference between the actual electrode potential and its equilibrium value) and could be positioned much closer to cathodes. Stable perfluorinated cation exchange membranes, such as DuPont Nafion ${ }^{\circledR}$ membranes, followed, replacing asbestos with a duration of about 6 months, by materials lasting 2 to 5 years. More efficient electrolysers containing these new cell components soon became commercially available. Gradual changeover to sophisticated plateand-frame type designs, such as INEOS' FM21 cells, has been taking place. Chloroalkali cell rooms became considerably cleaner and safer. But the benefits were even more widespread: these discoveries were rapidly taken up, translated and transferred into other electrochemical processes.

The US 1960s's space programme also gave rise to important advances including stable polymer materials, solid polymer electrolyte composites of membrane and electrode, and fuel cell electrodes for reacting oxygen and hydrogen feeds to produce power. Likewise, the demands of electrodialysis in salt splitting, product concentration, purification of process streams, and pollution control have been resulting in new ion-exchange membranes reaching the market. ${ }^{213,214}$ These are available as bipolar membranes, combining both anion and cation exchanging properties in a single material, and stable perfluorinated anion exchange membranes like those available from Tosoh in Japan.

The high melting salts that gained their importance when the industrial processes for aluminium and magnesium were developed are gaining new importance with their possibilities for the production of smaller quantities of other materials. For example, there are interesting applications of molten salts in electroplating and electrorefining of refractory metals and rare earth metals. Electrowinning of titanium has been tested on a pilot scale and electrodeposition of refractory compounds like $\mathrm{TiB}_{2}$ has also been demonstrated.

The recent development of ionic liquids and its emerging use in many industrial processes, ${ }^{108,210,211,215}$ namely in organic and inorganic manufacture of materials, also brings new possibilities in the field of electrosynthesis, and it is believed that in one or two decades they will have application in large scale productions. However, in the present situation, the use of ionic liquids should be treated with extreme caution, since most conversions in ionic liquids occur in the mg-scale, some of the liquids are ecological risky, very expensive, and are characterised by low diffusion coefficients, which requires large and expensive electrode areas.

\section{Electrosynthesis Future}

The tools are at hand! Flexible and affordable electrochemical cells are available from several suppliers. Only about a decade ago, such cells were just not available and the cost of developing suitable electrochemical reactor technology to meet companies' needs was often prohibitive. Nowadays, the necessary cell components including catalytic electrodes, membranes and stable gasketing materials are also commercially available on an "off-the-shelf" basis. And new cells, as well as more useful components, ${ }^{212,215-217}$ are being introduced rapidly. Significantly, the base knowledge has also increased remarkably over the last two decades through advances in electroanalytical techniques, ${ }^{126,218}$ chemical synthesis of promising electrolytes, ${ }^{219-221}$ progress in the electrochemical engineering field, ${ }^{222-228}$ and developments in electrocatalysis, ${ }^{212,229,230}$ which became a field that was once considered more art than science to one that is truly well technically grounded.

It is noticeable from the open literature $6,17,18,91,96,178,209$ that many companies throughout the world are 
taking advantage of these fast-breaking technological advances. Companies as Monsanto, 3M, Dow, Olin, Electrosynthesis and Reilly Chemical in the USA, Albright and Wilson, Noranda and Hydro Quebec in Canada, INEOS and ERDC in England, Isochem and Sorapec in France, BASF and Clariant in Germany, Akzo Nobel in the Netherlands, Asahi Chemical, Otsuka Chemical, Tokyo Carbon, Tokai and Tosoh in Japan, as well as many others, are actively engaged in discovering new opportunities to meet today's technological challenges. Their willingness to relate their valuable experience in technical articles has given courage to many other companies, and no doubt that we will soon witness a series of new success stories.

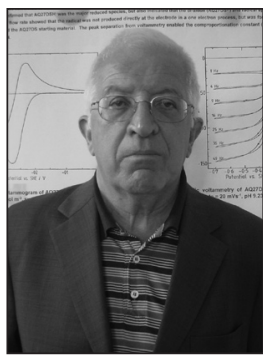

César Augusto Correia de Sequeira was born in Peso da Régua, Portugal, in 1943. On graduation in Chemical Engineering from the Technical University of Lisbon in 1968, he joined the staff of Instituto Superior Técnico as lecturer of Electrochemistry, Electrometallurgy and Electrothermy. In 1971 he started high temperature chemistry research in the Nuffield Research Group at Imperial College, obtaining a PhD from London University in October 1974. In the same year he returned to Lisbon and joined the University teaching staff, where he has been teaching and supervising research for more than 30 years. He spent one year (1982) with the Materials Development Division of the Atomic Energy Research Establishment (Harwell, U.K.), where he performed a fruitful research work on the development of all solid state polymerbased rechargeable lithium cells. He spent another year (1985-86) at the University of Utah, where he joined the research group of Prof. J. Janata on ion selective field effect transistors. He has directed several international projects on electrochemistry of hot corrosion, microbial corrosion, metal extraction, conducting polymers, energy storage and conversion. He is author/co-author of over 200 technical papers, editor/co-editor of 12 books, a frequent lecturer or panellist at scientific meetings, and is a Fellow of the Institute of Materials (U.K.), a Fellow of the Institute of Corrosion (U.K.), an Active Member of the Electrochemical Society (U.S.A.), a Founder Member of the Portuguese Electrochemical Society, the Portuguese Materials Society, and the Moscow International Energy Club. His present research interests include electrical and electrochemical properties of nanomaterials, hydrogen production and storage, and low temperature fuel cells.

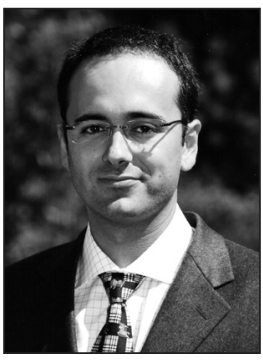

Diogo Miguel Franco dos Santos was born in Torres Vedras (Portugal) in 1977 and obtained his graduation in Chemical Engineering from Instituto Superior Técnico (TU Lisbon) in 2001. He received his MSc in 2006 for studying methods for analysis of boron compounds present in the electrosynthesis of sodium borohydride. Presently he is finishing his PhD in the field of the electrosynthesis of novel high-energy content materials, under the direction of Professor César Augusto Correia de Sequeira, at Instituto Superior Técnico. His main research interests are related to direct borohydride fuel cells and new materials for hydrogen storage.

\section{References}

1. Rapp, R. A.; Mater. Today 2006, 9, 6.

2. Grojtheim, K.; Krohn, C.; Malinovsky, M.; Matiasovsky, K.; Thonstad, J.; Aluminium Electrolysis - Fundamentals of the Hall-Heroult Process, $2^{\text {nd }}$ ed., Aluminium-Verlag: Düsseldorf, 1982.

3. Liu, Y. X.; Thonstad, J.; Electrochim. Acta 1983, 28, 113.

4. Lovering, D. G., ed. In Molten Salt Technology, Plenum Press: New York, 1982.

5. Busk, R. S., Magnesium Products Design, Marcel Dekker: New York, 1987.

6. Pütter, H. In Organic Electrochemistry, $4^{\text {th }}$ ed.; Lund, H.; Hammerich, O., eds.; Marcel Dekker: New York, 2001.

7. Steckhan, E.; Organic Electrochemistry, Ullmann's Encyclopedia of Industrial Chemistry, $6^{\text {th }}$ ed., Wiley-VCH: Weinheim, 1998.

8. Degner, D.; Top. Curr. Chem. 1988, 148, 1.

9. Torii, S.; Electrochemistry 2003, 71, 594.

10. Groult, H.; Lantelme, F.; Devilliers, D.; Belhomme, C.; Morel, B.; Nicolas, F.; Caire, J.-P.; Actual. Chim. 2006, 301-302, 40.

11. Noel, M.; Suryanarayanan, V.; J. Appl. Electrochem. 2004, 34, 357.

12. Ogibin, Y. N.; Nikishin, G. I.; Russ. Chem. Rev. 2001, 70, 543.

13. Jayaraman, K.; Noel, M.; Bull. Electrochem. 2001, 17, 227.

14. Pandey, P. C.; Prakash, R.; J. Electrochem. Soc. 1998, 145, 999.

15. Therese, G. H. A.; Kamath, P. V.; Chem. Mater. 2000, 12, 1195.

16. Vecchio-Sadus, A. M.; J. Appl. Electrochem. 1993, 23, 401.

17. Yoshida, J.; Kataoka, K.; Horcajada, R.; Nagaki, A.; Chem. Rev. 2008, 108, 2265.

18. Pletcher, D.; Walsh, F. C.; Industrial Electrochemistry, Chapman and Hall: London, 1990.

19. Wall, K.; Modern Chlor-Alkali Technology, Ellis Horwood Series in Industrial Chemistry, Ellis Horwood: Chichester, 1986, Vol. 3. 
20. Potapova, G. F.; Kasatkin, E. V.; Soviet Electrochem. 1988, 24, 253.

21. Vianin, L.; Comninellis, Ch.; Electrochim. Acta 1998, 43, 1109.

22. LeRoy, R. L.; Int. J. Hydrogen Energy 1983, 8, 401.

23. Wendt, H.; Imarisio, G.; J. Appl. Electrochem. 1988, 18, 1.

24. Galasiu, I.; Galasiu, R.; Thonstad, J. In Nonaqueous Electrochemistry; Aurbach, D., ed.; Marcel Dekker: New York, 1999.

25. Caldwell, D. L. In Comprehensive Treatise of Electrochemistry; Bockris, J. O. M.; Conway, B. E.; Yeager, E.; White, R. E., eds.; Plenum Press: New York, 1981, Vol. 2.

26. Ibl, N.; Vogt, H. In Comprehensive Treatise of Electrochemistry; Bockris, J. O. M.; Conway, B. E.; Yeager, E.; White, R. E., eds.; Plenum Press: New York, 1981, Vol. 2.

27. Hampel, C. A., ed. In Encyclopedia of Electrochemistry, Reinhold Publishing Corporation: New York, 1964.

28. Thiele, R.; Landsberg, R.; Z. Phys. Chem. 1967, 236, 261.

29. Tilak, B. V.; Lu, P. W. T.; Colman, G. E.; Srinivasan, S. In Comprehensive Treatise of Electrochemistry; Bockris, J. O. M.; Conway, B. E.; Yeager, E.; White, R. E., eds., Plenum Press: New York, 1981, Vol. 2.

30. Giannasi, F.; Int. J. Occup. Environ. Health 2007, 13, 80.

31. Dötzel, O.; Schneider, L.; Chem. Eng. Technol. 2002, 25, 167.

32. Hua, R.; Chen, B.; Appl. Finan. Econ. 2007, 17, 1275.

33. Vrioni, G.; Deves, J.; Acta Microbiol. Hellen. 2007, 52, 318.

34. Sim, P. H.; Chem. Week 2007, 169, 39.

35. Douglas, B.; Pulp Pap. Can. 2007, 108, 14.

36. Paleologou, M.; Wong, P. Y.; Thompson, R.; Berry, R. M.; J. Pulp Pap. Sci. 1996, 22, J1.

37. Tzanetakis, N.; Taama, W.; Scott, K.; Filtr. Sep. 2002, 39, 30.

38. Van der Bruggen, B.; Koninckx, A.; Vandecasteele, C.; Water Res. 2004, 38, 1347.

39. Raucq, D.; Pourcelly, G.; Gavach, C.; Desalination 1993, 91, 163.

40. Paleologou, M.; Thibault, A.; Wong, P.-Y.; Thompson, R.; Berry, R. H.; Sep. Purif. Technol. 1997, 11, 159.

41. Yazicigil, Z.; Desalination 2007, 212, 70.

42. Thatcher, C. J.; Trans. Am. Electrochem. Soc. 1919, 36, 337.

43. Danly, D. E.; J. Electrochem. Soc. 1984, 131, 435C.

44. Pezzatini, G.; Becagli, S.; Innocenti, M.; Foresti, M. L.; Guidelli, R.; J. Electroanal. Chem. 1999, 462, 127.

45. Becker, J. Y.; Koch, T. A.; Electrochim. Acta 1994, 39, 2067.

46. Moncelli, M. R.; Guidelli, R.; Cariá, M.; J. Electroanal. Chem 1991, 313, 313 .

47. Kinlen, P. J.; King, J. H.; J. Electroanal. Chem. 1991, 304, 133.

48. Scott, K.; Hayati, B.; Haines, A. N.; McConvey, I. F.; Chem. Eng. Technol. 1990, 13, 376.

49. Doherty, A. P.; Christensen, P. A.; Hamnett, A.; Scott, K.; J. Electroanal. Chem. 1995, 386, 39.
50. Hara, Y.; Watanabe, E.; Wada, K.; Onoda, T.; J. Organomet. Chem. 1989, 359, 97.

51. Ishino, M.; Tamura, M.; Deguchi T.; Nakamura, S.; J. Catal. 1992, 133, 325 .

52. Ishino, M.; Tamura, M.; Deguchi T.; Nakamura, S.; J. Catal. 1992, 133, 332

53. Maitlis, P. M.; J. Mol. Catal. A: Chem. 2003, 204-205, 55.

54. Fishman, A.; Acton, A.; Lee-Ruff, E.; Synth. Commun. 2006, 36,327

55. England, P. A.; Harford-Cross, C. F.; Stevensen, J.-A.; Rouch, D. A.; Wong, L.-L.; FEBS Lett. 1998, 424, 271.

56. Shie, J.-L.; Chang, C.-Y.; Chen, J.-H.; Tsai, W.-T.; Chen, Y.-H.; Chiou, C.-S.; Chang C.-F.; Appl. Catal., B 2005, 58, 289.

57. Shylesh, S.; Singh, A. P.; J. Catal. 2004, 228, 333.

58. Khavasi, H. R.; Davarani, S. S. H.; Safari, N.; J. Mol. Catal. A: Chem. 2002, 188, 115.

59. Fang, J.; Barcelona, M. J.; Chemosphere 2003, 50, 105.

60. Bisach-Wittmeyer, A.; Sido, A. S. S.; Guiline, P.; Désaubry, L.; Bioorg. Med. Chem. Lett. 2005, 15, 3609.

61. Abreu, F. C.; Lopes, A. O.; Pereira, M. A.; Simone, C. A.; Goulart, M. O. F.; Tetrahedron Lett. 2002, 43, 8153.

62. Moteki, J.; Sykes, A. G.; J. Electroanal. Chem. 1998, 447, 91.

63. Ohno, T.; Tokieda, K.; Higashida, S.; Matsumara, M.; Appl. Catal., A 2003, 244, 383.

64. Utley, J. H. P.; Rozenberg, G. G.; Tetrahedron 2002, 58, 5251.

65. Amatore, C.; Brown, A. R.; J. Am. Chem. Soc. 1996, 118, 1482 .

66. Conte, L.; Gambaretto, G. P.; J. Fluorine Chem. 2004, 125, 139.

67. Ignat'ev, N.; Sartori, P.; J. Fluorine Chem. 2000, 101, 203.

68. Pud, A. A.; Shapoval, G. S.; Kukhar, V. K.; Mikulina, D. E.; Gervits, L. L.; Electrochim. Acta 1995, 40, 1157.

69. Shodai, Y.; Inaba, M.; Onoda, K.; Akimasa, T.; J. Rare Earths 2006, 24,1 .

70. Ignat'ev, N.; Datsenko, S.; J. Fluorine Chem. 1992, 58, 271.

71. Sisa, M.; Hnilicková, J.; Swaczynová, J.; Kohout, L.; Steroids 2005, 70, 755 .

72. Lehmler, H.-J.; Chemosphere 2005, 58, 1471.

73. Nenajdenko, V. G.; Varseev, G. N.; Korotchenko, V. N.; Shastin, A. V.; Babenkov, E. S.; J. Fluorine Chem. 2004, 125, 1339.

74. Sandford, G.; Tetrahedron 2003, 59, 437.

75. Wiedenfeld, D.; Niyogi, S.; Chakrabarti, D.; J. Fluorine Chem. 2000, 104, 303.

76. Li, J.; Hu, X.; Su, Y.; Li, Q.; Chem. Eng. Sci. 2007, 62, 6784.

77. Deffernez, A.; Hermans, S.; Devillers, M.; Appl. Catal., A 2005 , $282,303$.

78. Alardin, F.; Wullens, H.; Hermans, S.; Devillers, M.; J. Mol. Catal. A: Chem. 2005, 225, 79.

79. Ye, Y.-M.; Chen, F.-C.; Modern Chem. Ind. 2003, 23, 72. 
80. Chen, S.-P.; Huang, T.; Sun, S.-G.; J. Chromatogr. A 2005, 1089, 142 .

81. Sanchez-Cano, G.; Montiel, V.; Aldaz, A.; Tetrahedron 1991, 47, 877.

82. Wang, Q.-F.; Shi, F.; Mi, Z.-T.; Zhang, X.-W.; Wang, L.; Chin. J. Energ. Mater. 2007, 15, 416.

83. Schofield, K.; Aromatic Nitration, Cambridge University Press: Cambridge, 1980.

84. Stevens, T. E.; Emmons, W. D.; J. Am. Chem. Soc. 1957, 79, 6008.

85. Robson, J. H.; J. Am. Chem. Soc. 1955, 77, 107.

86. Farbwerke Hoechst; Germ. pat. 871,744 1938.

87. Harris, A. D.; Trebellas, J. G.; Jonassen, H. B.; Inorg. Synth. 1967, 9,83 .

88. Anon.; Germ. pat. 231,546 1910.

89. Wang, Q.; Su, M.; Zhang, X.; Wang, L.; Wang, J.; Mi, Z.; Electrochim. Acta 2007, 52, 3667.

90. Harrar, J. E.; Quong, R.; Rigdon, L. P.; McGuire, R. R.; J. Electrochem. Soc. 1997, 144, 2032.

91. ICI Publication, Electrotech. Review, Issue 5, 1991.

92. Wang, Q.; Su, M.; Zhang, X.; Wang, L.; Wang, J.; Mi Z.; Electrochim. Acta 2007, 52, 3667.

93. Talawar, M. B.; Sivabalan, R.; Polke, B. G.; Nair, U. R.; Gore, G. M.; Asthana, S. N.; J. Hazard. Mater. 2005, 124, 153.

94. Roquero, P.; Cognet, P.; Duverneuil, P.; Lacoste, G.; Fabre, P.-L.; J. Appl. Electrochem. 1998, 28, 475.

95. Hirashima, T.; Nishiguchi, I.; J. Synth. Org. Chem. 1985, 43, 634.

96. Weinberg, N. L.; Little, D., eds. In Festschrift in Honor of Manuel M. Baizer, Marcel Dekker: New York, 1991.

97. Rode, S.; Altmeyer, S.; Matlosz, M.; J. Appl. Electrochem. 2004, 34,671 .

96. Torii, S.; Novel Trends in Electroorganic Synthesis, SpringerVerlag: New York, 1998.

97. Walden, P.; Bull. Acad. Imper. Sci. (St. Petersburg) 1914, 8, 405.

99. Hurley, F. H.; Wier, T. P.; J. Electrochem. Soc. 1951, 98, 203.

100. Caja, J.; Dunstan, T. D. J.; Ryan, D. M.; Katovic, V.; Proc. Electrochem. Soc. 2000, 99-41, 150.

102. Mamantov, G.; Marassi, A., eds. In Molten Salt Chemistry, D. Reidel: New York, 1987.

103. Hussey, C. L.; Pure Appl. Chem. 1988, 60, 1763.

104. Mamantov, G.; Popov, A. I., eds. In Chemistry of Non-Aqueous Solutions - Current Progress, VCH: New York, 1994.

105. Seddon, K. R.; Kinet. Catal. 1996, 37, 693.

106. Cornils, B.; Herrmann, W. A., eds. In Aqueous-Phase Organometallic Catalysis: Concepts and Applications, WileyVCH: Weinheim, 1998.

107. Wasserscheid, P.; Welton, T., eds. In Ionic Liquids in Synthesis, Wiley-VCH: Weinheim, 2003.

108. Plechkova, N. V.; Seddon, K. R.; Chem. Soc. Rev. 2008, 37, 123.
109. Badri, M.; Brunet, J.-J.; Perron, R.; Tetrahedron Lett. 1992, 33, 4435.

110. Suarez, P. A. Z.; Dullins, J. E. L.; Einloft, S.; de Sousa, R. F.; Dupont, J.; J. Inorg. Chim. Acta 1997, 255, 207.

111. Chauvin, Y.; Mussmann, L.; Olivier, H.; Angew. Chem. Int. Ed. Engl. 1995, 34, 2698.

112. Silva, S. M. P.; Suarez, A. Z.; de Sousa, R. F.; Dupont, J.; Polym. Bull. 1998, 40, 401.

113. Varma, R. S.; Namboodiri, V. V.; Chem. Commun. 2001, 643.

114. Favre, F.; Olivier-Bourbigou, H.; Commereuc, D.; Saussine, L.; Chem. Commun. 2001, 1360.

115. Geldbach, T. J.; Dyson, P .J.; Metal Catalysed Reactions in Ionic Liquids, Springer: New York, 2005.

116. Dyson, P. J.; Geldbach, T. J.; Electrochem. Soc Interface 2007, 16,50 .

117. Geldbach, T. J.; Zhac, D.; Castillo, N. C.; Laurenczy, G.; Weyershausen, B.; Dyson, P. J.; J. Am. Chem. Soc. 2006, 128, 9773.

118. Welton, T.; Chem. Rev. 1999, 99, 2071.

119. Ito, Y.; Nohira, T.; Electrochim. Acta. 2000, 45, 2611.

120. Welton, T.; Coord. Chem. Rev. 2004, 248, 2459.

121. Webb, P. B.; Kunene, T. E.; Cole-Hamilton, D. J.; Green Chem. 2005, 7, 373.

122. Buzzeo, M. C.; Evans, R. G.; Compton, R. G.; Phys. Chem. Chem. Phys. 2004, 5, 1107.

123. Lagrost, C.; Hapiot, P.; Vaultier, M.; Green Chem. 2005, 7, 468.

124. Zhang, J.; Bond, A. M.; Analyst 2005, 130, 1132.

125. Ngo, H. L.; LeCompte, K.; Hargens, L.; McEwen, A. B.; Thermochim. Acta 2000, 357-358, 97.

126. Kissinger, P. T.; Heineman, W. R., eds. In Laboratory Techniques in Electroanalytical Chemistry, Marcel Dekker: New York, 1984.

127. McEwen, A. B.; Goldman, J. L.; Wassel, D.; Hargens, L.; Proc. Electrochem. Soc. 2000, 99-41, 222.

128. Carlin, R. T.; Osteryoung, R. A.; J. Electroanal. Chem. 1988 , 252,81 .

129. Simonsen, L. R.; Donahue, F. M.; Electrochim. Acta 1990, 35, 87.

130. Carmichael, A. J.; Hardacre, C.; Holbrey, J. D.; Seddon, K. R.; Nieuwenhuyzen, M.; Proc. Electrochem. Soc. 2000, 99-41, 209.

131. Hagiwara, R.; Ito, Y.; J. Fluorine Chem. 2000, 105, 221.

132. Seddon, K. R.; Stark, A.; Torres, M.-J.; Pure Appl. Chem. 2000 , 72,2275 .

133. Holbrey, J. D.; Seddon, K. R.; Wareing, R.; Green Chem. 2001, 3,33 .

134. Aki, S. N. V. K.; Brennecke, J. F.; Samanta, A.; Chem. Commun. 2001, 413.

135. Carmichael, A. J.; Seddon, K. R.; J. Phys. Org. Chem. 2000 , $13,591$. 
136. Fischer, T.; Sethi, A.; Welton, T.; Woolf, J.; Tetrahedron Lett. 1999, 40, 793.

137. Muldoon, M. J.; Gordon, C. M.; Dunkin, I. R.; J. Chem. Soc., Perkin Trans. 2001, 2, 433.

138. Wasserscheid, P.; Gordon, C. M.; Hilgers, E.; Muldoon, M. J.; Dunkin, I. R.; Chem. Commun. 2001, 1186.

139. Chen, P.-Y.; Lin, Y.-F.; Sun, I.-W.; J. Electrochem. Soc. 1999, 146, 3290.

140. Liu, J. S.-Y.; Sun, I.-W.; J. Electrochem. Soc. 1997, 144, 140.

141. Jeng, E. G.-S.; Sun, I.-W.; J. Electrochem. Soc. 1998, 145, 1196.

142. Xu, X.-H.; Hussey, C. L.; J. Electrochem. Soc. 1993, 140, 618.

143. Hussey, C. L.; Xu., X.; J. Electrochem. Soc. 1991, 138, 1886.

144. Habboush, D. A.; Osteryoung, R. A.; Inorg. Chem. 1984, 23, 1726.

145. Heerman, L.; D’Olieslager, W.; J. Electrochem. Soc. 1991, 138, 1372.

146. Jeng, E. G.-S.; Sun, I.-W.; J. Electrochem. Soc. 1997, 144, 2369.

147. Laher, T. M.; Hussey, C. L.; Inorg. Chem. 1982, 21, 4079.

148. Hussey, C. L.; Laher, T. M.; Inorg. Chem. 1981, 20, 4201.

149. Carlin, R. T.; Trulove, P. C.; De Long, H. C.; J. Electrochem. Soc. 1996, 143, 2747.

150. Tierney, B. J.; Pitner, W. R.; Mitchell, J. A.; Hussey, C. L.; Strafford, G. R.; J. Electrochem. Soc. 1998, 145, 3110.

151. Pitner, W. R.; Hussey, C. L.; J. Electrochem. Soc. 1997, 144, 3095.

152. Zhu, Q.; Hussey, C. L.; Strafford, G. R.; J. Electrochem. Soc. 2001, 148, C88.

153. Freyland, W.; Zell, C. A.; El Abedin, S.-Z.; Electrochim. Acta 2003, 48, 3053.

154. Endres, F.; Schrodt, C.; Phys. Chem. Chem. Phys. 2000, 2, 5517.

155. Endres, F.; Phys. Chem. Chem. Phys. 2001, 3, 3165.

156. Yang, M. H.; Sun, I.-W.; J. Appl. Electrochem. 2005, 33, 1077.

157. Koura, N.; Suzuki, Y.; Idemoto, Y.; Kato, T.; Matsumoto, F.; Surf. Coat. Technol. 2003, 169, 120.

158. Huang, J.-F.; Sun, I.-W.; J. Electrochem. Soc. 2004, 151, C8.

159. Matsumoto, H.; Yanagida, M.; Tanimoto, K.; Nomura, M.; Kitagawa, Y.; Miyazaki, Y.; Chem. Lett. 2000, 29, 922.

160. Sun, J.; MacFalane, D. R.; Forsyth. M.; Electrochim. Acta 2003, 48, 1707.

161. Sakaebe, H.; Matsumoto, H.; Electrochem. Commun. 2003, 5 , 594.

162. Katayama, Y.; Morita, T.; Yamagata, M.; Miura, T.; Electrochemistry 2003, 71, 186.

163. Yamagata, M.; Katayama, Y.; Miura, T.; Proc. Electrochem. Soc. 2002, 19, 640.

164. Tsuda, T.; Ito., Y.; Proc. Electrochem. Soc. 2000, 99-41, 100.
165. Carpenter, M. K.; Verbrugge, M. W.; J. Mater. Res. 1994, 9, 2584.

166. Gregory, B.; Stickney, J. L.; J. Electroanal. Chem. 1994, 365, 87.

167. Raza, A.; Engelken, R.; Kemp, B.; Siddiqui, A.; Mustafa, O.; Proc. Arkansas Acad. Sci. 1995, 49, 143.

168. Verbrugge, M. W.; Carpenter, M. K.; AIChE J. 1990, 36, 1097.

169. Wicelinski, S. P.; Gale, R. J.; Wilkes, J. S.; J. Electrochem. Soc. 1987, 134, 262.

170. Carpenter, M. K.; Verbrugge, M. W.; J. Electrochem. Soc. 1987, $134,591$.

171. Lin, M.-C.; Chen, P.-Y.; Sun, Y.-W.; J. Electrochem. Soc. 2001, 148, C653.

172. Zell, C. A.; Endres, F.; Freyland, W.; Phys. Chem. Chem. Phys. 1999, 1, 697.

173. Gewirth, A. A.; Siegenthaler, H., eds. In Nanoscale Probes of the Solid/Liquid Interface, Kluwer Academic Publishers: Dordrecht, 1995.

174. Tang, M. C.-Y.; Wong, K.-Y; Chen, T. H.; Chem. Commun. 2005, 1345.

175. Ishii, H.; Fuchigami, T.; Electrochemistry 2002, 70, 46.

176. Fuchigami, T.; Atobe, M.; Mater. Integr. 2003, 16, 20.

177. Mariano, P. S., ed. In Advances in Electron Transfer Chemistry, JAI Press: New York, 1999, Vol. 6.

178. Lund, H.; Hammerich, O., eds. In Organic Electrochemistry, $4^{\text {th }}$ ed., Marcel Dekker: New York, 2001.

179. Meurs, J. H. H.; Eilenberg, W.; Tetrahedron 1991, 47, 705.

180. Fuchigami, T.; Shimojo, M.; Konno, A.; Nakagawa, K.; J. Org. Chem. 1990, 55, 6074

181. Brigaud, T.; Laurent, E.; Tetrahedron Lett. 1990, 31, 2287.

182. Fuchigami, T.; Shimojo, M; Konno, A.; J. Org. Chem. 1995, $60,3459$.

183. Momota, K.; Morita, M.; Matsuda, Y.; Electrochim. Acta 1993, $38,1123$.

184. Momota, K.; Yonezawa, T.; Hayakawa, Y.; Kato, K.; Morita, M.; Matsuda, Y.; J. Appl. Electrochem. 1995, 25, 651.

185. Momota, K.; Horio, H.; Kato, K.; Morita, M.; Matsuda, Y.; Electrochim. Acta 1995, 40, 233.

186. Momota, K.; Horio, H.; Kato, K.; Morita, M.; Matsuda, Y.; Electrochemistry 1994, 62, 1106.

187. Momota, K.; Mukai, K.; Kato, K.; Morita, M.; Electrochim. Acta 1998, 43, 2503

188. Momota, K.; Mukai, K.; Kato, K.; Morita, M.; J. Fluorine Chem. 1998, 87, 173.

189. Saeki, K.; Tmomizitsu, M.; Kawazor, Y.; Momota, K.; Kimoto, H.; Chem. Pharm. Bull. 1996, 44, 2254.

190. Hasegawa, M.; Ishii, M.; Fuchigami, T.; Tetrahedron Lett. 2002, 43,1502 .

191. Hasegawa, M.; Ishii, H.; Fuchigami, T.; Green Chem. 2003, 5, 512.

192. Hasegawa, M.; Fuchigami, T.; Electrochim. Acta 2004, 49, 3367. 
193. Barhdadi, R.; Courtinard, C.; Nédélec, J. Y.; Troupel, M.; Chem. Commun. 2003, 9, 1434.

194. Martiz, B. A.; Keyrouz, R. B.; Gmouh, S. B.; Vaultier, M. B.; Jouikov, V. B.; Chem. Commun. 2004, 10, 674.

195. Danielsson, P.; Bobacka, J.; Ivaska, A.; J. Solid. St. Electrochem. 2004, 8, 809.

196. Doherty, A. P.; Brooks, C. A.; Electrochim. Acta 2004, 49, 3821.

197. Mellah, M.; Zeitouny, J.; Gmouh, S.; Vaultier, M.; Jounikov, V.; Electrochem. Commun. 2005, 7, 869.

198. Lu, W.; Faceev, A. G.; Qi, B.; Smela, E.; Mattes, B. R.; Ding, J.; Spinks, G. M.; Mazurkiewicz, J.; Zhou, D.; Wallace, G. G.; MacFarlane, D. R.; Forsyth, S. A.; Forsyth, M.; Science 2002, 297, 983.

199. Sakiguchi, K.; Atobe, M.; Fuchigami, T.; Electrochem. Commun. 2002, 4, 881.

200. Sekiguchi, K.; Atobe, M.; Fuchigami, T.; J. Electroanal. Chem. 2003, 557, 1.

201. Du, Y.; Wang, H.; Zhang, A.; Lu, J.; Chinese Sci. Bull. 2007, $52,2174$.

202. Zane, D. A.; Raffaele, A. A.; Curulli, A. A.; Appetechi, G. B. B.; Passerini, S. B.; Electrochem. Commun. 2007, 9, 2037.

203. Qi, X.; Du, Y.; Zhang, G.; Zhao, P.; Lu, J.; Front. Chem. China 2006, 1, 345.

204. Yang, H.; Gu, Y.; Deng, Y.; Shi, F.; Chem. Commun. 2002, 274.

205. Mellah, M.; Gmouh, S.; Vaultier, M.; Jouikov, V.; Electrochem. Commun. 2003, 5, 591 .

206. Lu, J.-X.; Sun, Q.; He, M.-Y.; Chinese J. Chem. 2003, 21, 1229.

207. Silvester, D. S.; Compton, R. G.; Z. Phys. Chem. 2001, 220, 1247.

208. Fuchigami, T.; Funct. Mater. 2004, 24, 20.

209. Szánto, D.; Trinidad, P.; Walsh, F.; J. Appl. Electrochem. 1998, $28,251$.

210. Hapiot, P.; Lagrost, C.; Chem. Rev. 2008, 108, 2238.

211. Dupont, J.; Consorti, C. S.; Spencer, J.; J. Braz. Chem. Soc. 2000, 11, 337 .
212. Eftekhari, A., ed. In Nanostructured Materials in Electrochemistry, Wiley-VCH: Weinheim, 2008.

213. Tsuneda, S.; Saito, K.; Mitsuhara, H.; Sugo, T.; J. Electrochem. Soc. 1995, 142, 3659.

214. Huang, C.; Xu, T.; Jacobs, M. L.; AIChE J. 2006, 52, 393.

215. Ohno, H., ed. In Electrochemical Aspects of Ionic Liquids, John Wiley \& Sons: Hoboken, NJ, 2005.

216. Shobha, T.; Mayanna, S. M.; Sequeira, C. A. C.; J. Power Sources 2002, 108, 261.

217. Sequeira, C. A. C.; Ministro, P. M. C.; Corros. Prot. Mater. 1985, 4, 112.

218. Bard, A. J.; Faulkner; L. R.; Electrochemical Methods Fundamentals and Applications, $2^{\text {nd }}$ ed., John Wiley \& Sons: Hoboken, NJ, 2001.

219. Li, M. C.; Ma, C. A.; Liu, B. Y.; Jin, Z. M.; Electrochem. Commun. 2005, 7, 209.

220. Nie, J.; Li, X.; Liu, D.; Luo, R.; Wang, L.; J. Fluorine Chem. 2004, 125, 27.

221. Liew, M. J.; Roy, S.; Scott, K.; Green Chem. 2003, 5, 376.

222. Scott, K.; Electrochemical Reaction Engineering, Academic Press: London, UK, 1991.

223. Sequeira, C. A. C.; Picard, G. S., eds. In Electrochemical Technology of Molten Salts, Trans. Tech. Publications: Aedermansdorf, 1993.

224. Grotheer, M.; Alkire, R.; Varjtan, R.; Srinivasan, V.; Weidner, J.; Electrochem. Soc. Interface 2006, 15, 52.

225. Vijayasekaran, B.; Basha, C. A.; Trans. SAEST 2005, 40, 1.

226. Lapicque, F.; Chem. Eng. Res. Des. 2004, 82, 1571.

227. Alkire, R. C.; Braatz, R. D.; AIChE J. 2004, 50, 2000.

228. Sequeira, C. A. C.; C. Tecn. Mat. 1996, 8, 6.

229. Shan, Y.; Yang, G.; Gong, J.; Zhang, X.; Zhu, L.; Qu, L.; Electrochim. Acta 2008, 53, 7751.

230. Sequeira, C. A. C.; Santos, D. M. F.; Brito, P. S. D.; Appl. Surf. Sci. 2006, 252, 6093.

Received: April 22, 2008 Web Release Date: February 6, 2009 